\title{
Chemical characterisation of total suspended particulate matter from a remote area in Amazonia
}

\author{
Cátia Gonçalves ${ }^{\mathrm{a}, *}$, Bernardino R. Figueiredo ${ }^{\mathrm{a}}$, Célia A. Alves ${ }^{\mathrm{b}}$, Arnaldo A. Cardoso ${ }^{\mathrm{c}}$, Rodrigo da Silva ${ }^{\mathrm{d}}$, \\ Simone H. Kanzawa ${ }^{a}$, Ana Margarida Vicente ${ }^{b}$ \\ a Department of Geology and Natural Resources, Institute of Geosciences, University of Campinas, 13083-870 Campinas, SP, Brazil \\ b CESAM, Department of Environment, University of Aveiro, 3810-193 Aveiro, Portugal \\ c Department of Analytical Chemistry, Institute of Chemistry, Júlio de Mesquita Filho State University of São Paulo, 14800-900 Araraquara, SP, Brazil \\ d Institute of Engineering and Geosciences, Oeste do Pará Federal University, 68040-470 Santarém, PA, Brazil
}

\section{A R T I C L E I N F O}

\section{Article history:}

Received 26 January 2016

Received in revised form 13 July 2016

Accepted 23 July 2016

Available online 26 July 2016

\section{Keywords:}

Water-soluble ions

Elements

Organic speciation

TSP

Amazonia

\begin{abstract}
A B S T R A C T
This research had as study object the total suspended particulate matter collected in the Alenquer region, a remote area in the Pará state. The main objectives were the characterisation of the inorganic and organic chemical composition of the aerosol, looking for seasonal patterns and the identification of probable emission sources and formation processes. A set of 30 samples were collected in the rainy (April-May) and dry season (August-September) of 2014. The analytical methods included gravimetric analysis, water-soluble ions analysis by ion chromatography (IC), elemental analysis by inductively coupled plasma mass spectrometry (ICP-MS) equipped with collision cell technology, carbonaceous content determination with a thermal-optical system and organic speciation by gas chromatography-mass spectrometry (GC-MS). The average concentrations of particulate matter ranged from $14 \pm 1.3 \mu \mathrm{g} \cdot \mathrm{m}^{-3}$ to $31 \pm 7.8 \mu \mathrm{g} \cdot \mathrm{m}^{-3}$, in the rainy and dry season, respectively. The carbonaceous content represented, on average, approximately $27 \%$ and $21 \%$ of the particulate matter in the rainy and dry season, respectively. $\mathrm{Na}^{+}, \mathrm{Cl}^{-}, \mathrm{SO}_{4}{ }^{2-}$, and $\mathrm{NO}_{3}{ }^{-}$yield the highest concentrations in both seasons. Na was the dominant element, reflecting the transport of air masses from the Atlantic. An increase in concentrations between the rainy and dry seasons was especially noted for the terrigenous elements such Mn, Fe and Al. The chromatographically resolved organics included $n$-alkanes, $n$-alkenes, PAHs, $n$-alkanoic acids, $n$-di-acids, resin acids and some phenolic compounds. The primary inputs of organic constituents to the aerosols of Alenquer based on the homologous compound series and biomarkers were: (i) natural emissions from terrestrial higher plants waxes, particularly in dry season; (ii) anthropogenic emissions from diesel fuel combustion and biomass combustion, predominating during the dry season. The chemical characterisation along with the backward trajectory cluster analysis suggests a great influence from natural sources such as marine aerosol, mainly in the rainy season. In the dry season, the region is also affected by soil dust re-suspension and some biomass burning.
\end{abstract}

(c) 2016 Elsevier B.V. All rights reserved.

\section{Introduction}

Amazonia is simultaneously a natural and anthropogenic source of aerosols. Its tropical location, the flora and fauna variety and the intense metabolism of all living beings, make the Amazonia a natural source of aerosols. It is also a source of anthropogenic particles, especially during the dry season, due to forest fires (in pasture areas and primary forest), dust resuspension as a result of agricultural, deforestation and urban activities (Andreae and Crutzen, 1997). All the chemical compounds arising from such processes can reach high altitudes and be carried to long distances. Consequently, Amazonia can be recognised as one of the major direct sources of aerosol particles (mainly organic aerosols)

\footnotetext{
* Corresponding author.

E-mail address: catiagoncalves@ige.unicamp.br (C. Gonçalves).
}

to the global atmosphere (Andreae et al., 2002; Crozat, 1979). The Amazonia region is also affected by aerosol particles resulting from long-distance transport, such as mineral dust and biomass burning particles from North Africa, and marine particles with Atlantic origin (Artaxo et al., 2002; Chen et al., 2009; Guyon et al., 2003; Swap et al., 1992). Atmospheric processes are major drivers of climate variability and interact with diverse components and functions of ecosystems at various scales. Aerosols affect the Earth's climate both directly (by scattering and absorbing radiation) and indirectly (by serving as nuclei for cloud formation). They provide sites for surface chemistry and condensed-phase chemistry to take place in the atmosphere. Aerosol particles also exert a fundamental role in the biogeochemistry of ecosystems and nutrient cycles (Artaxo et al., 2002). In remote areas of Amazonia, the two main sources of natural aerosol particles are the direct emission of biogenic particles, and the oxidation of volatile 
organic compounds (VOC) emitted by the vegetation which are subject to chemical and photochemical processes giving rise to new aerosol particles. Despite the relatively vast area of tropical forests, throughout the years, only a few studies involving the chemical characterisation of natural aerosol particles in remote areas of Amazonia rain forest have been undertaken. Most studies have focused on the inorganic composition, encompassing elements and ions (Artaxo et al., 1990; Artaxo and Hansson, 1995; Gonçalves and Figueiredo, 2015; Echalar et al., 1998; Graham et al., 2003a). Studies focused on the organic components of aerosol particles are even more limited (Claeys et al., 2004; Graham et al., 2003b; Kesselmeier et al., 2000; Simoneit et al., 1990; Vasconcellos et al., 1998). Furthermore, Amazonia has been subject to an intensive process of land use and human activities change, even in some of these more remote areas. Baseline knowledge of the source strengths, properties and processes of aerosols is necessary to correctly assess present-day burdens and contribute with new data for the maintenance and preservation of this territory in the future.

The city of Alenquer was chosen to carry out this study because of its remote location and low anthropogenic influence, which makes it a suitable place to understand the natural characteristics of the region. It may be considered a natural laboratory for understanding the effects of anthropogenic pollution on the aerosol life cycle in the tropics. The main objectives were to accomplish a detailed chemical characterisation of the total suspended particulate matter (TSP), to look for seasonal patterns and to identify potential emission sources and formation processes.

\section{Methodology}

\subsection{Studied area and sampling details}

The sampling station was located near the Uruxi lake $\left(01^{\circ} 57^{\prime} 49^{\prime \prime}\right.$ $\left.\mathrm{S}, 54^{\circ} 41^{\prime} 41^{\prime \prime} \mathrm{W}\right), 7 \mathrm{~km}$ from Alenquer and about $12 \mathrm{~m}$ above sea level
(Fig. 1). Alenquer is located in the Lower Amazon mesoregion of the Para state and has 54,353 inhabitants (IBGE, 2015). The Amazon River and Uruxi lake are in the southwest and east of the study area, respectively. Alenquer's economy is based in activities such as services, agriculture and cattle raising, industry (dairy cooperative, timber extraction and ice production) and traditional fishing (Silva Junior and Szlafsztein, 2013). A meteorological station was installed for the characterisation of meteorological parameters such as temperature, relative humidity and precipitation. All meteorological parameters were continuously measured using a Campbell Scientific data logger CR1000 model, a multi-parameter sensor Vaisala WX520 and a Campbell solar panel $10 \mathrm{~W}$. In Northern Brazil the seasons are differentiated according to the monthly distribution of rainfall: the rainy season occurs between November and May, being March and April the wettest months; the dry season occurs between June and October, being August the month with the lowest rainfall (Arana and Artaxo, 2014; Falesi, 1971). Taking this into account, two sampling campaigns were carried out: the first campaign took place between April 20 and May 5 of 2014, coinciding with the rainy season; the second campaign was conducted between August 18 and September 2 of 2014, coinciding with the dry season. A total of 30 samples were obtained. The particulate material was collected on quartz fibre filters (Whatman) with a high volume sampler for TSP (flow rate: $\sim 1.5 \mathrm{~m}^{3} \mathrm{~min}^{-1}$ ) for $24 \mathrm{~h}$ periods. Following the sample collection, filters were stored in a freezer (at $-14{ }^{\circ} \mathrm{C}$ ) prior to analysis. To better understand the influence of atmospheric transport on aerosol properties, backward trajectory cluster analysis was carried out using the Hybrid Single Particle Lagrangian Integrated Trajectory (HYSPLIT) model developed by NOAA's Air Resources Laboratory (Draxler and Hess, 1997, 1998) with meteorological data from GDAS (Global Data Analysis System). Ten days $(240 \mathrm{~h}$ ) backward trajectories ending at the sampling place were calculated.

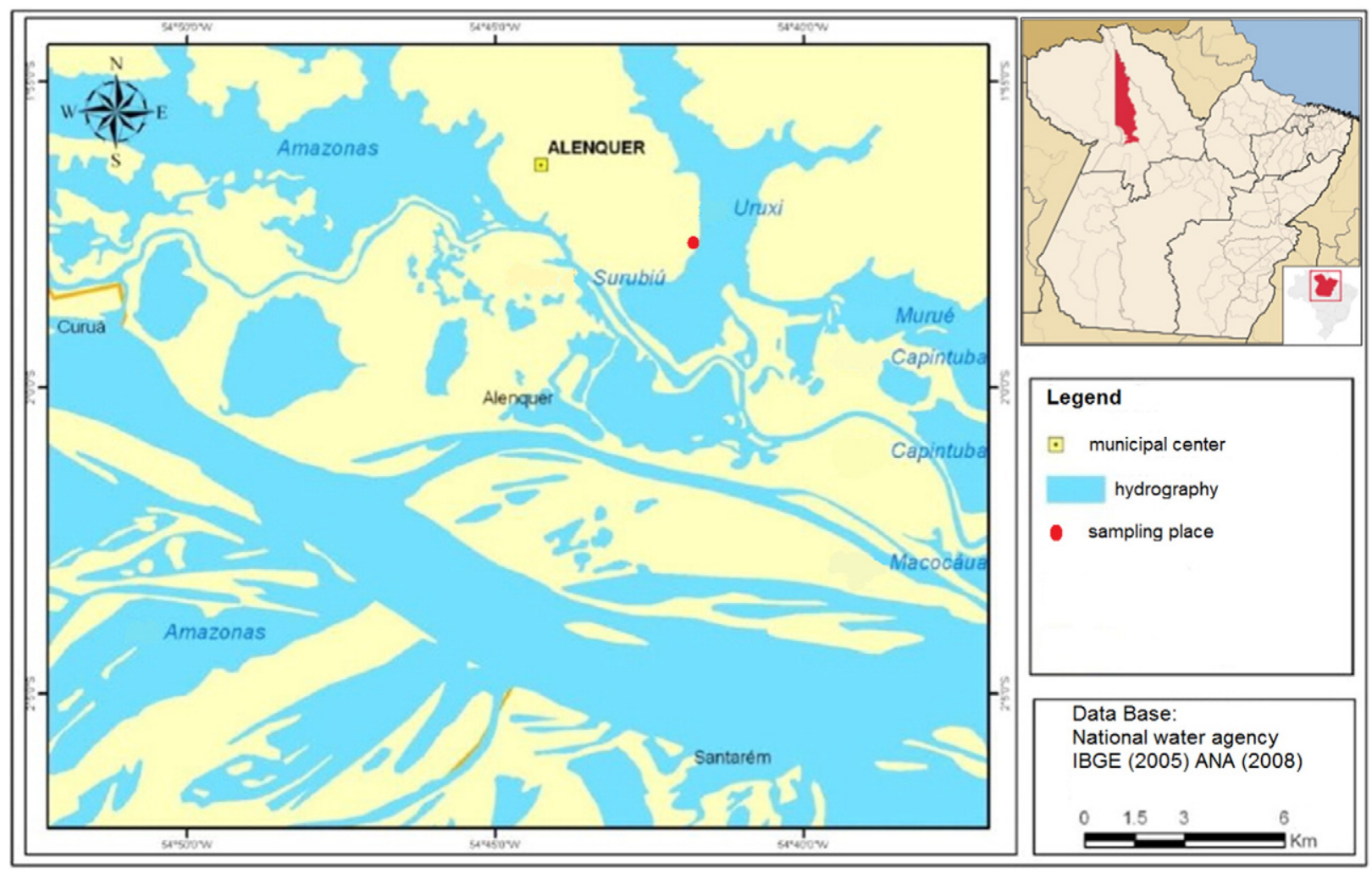

Fig. 1. Sampling place and Alenquer city location map. (adapted from Silva Junior and Szlafsztein, 2013) 


\subsection{Analytical methods}

Gravimetric analysis was performed with a microbalance (Sartorius CP225D) after 24 h equilibration in a room with controlled temperature and relative humidity $\left(20 \pm 2{ }^{\circ} \mathrm{C} ; 50 \pm 5 \%\right)$. Quartz fibre filters used in this study were placed in an oven at $500{ }^{\circ} \mathrm{C}$ for $6 \mathrm{~h}$, to remove organic contamination, before use. Filter weight before and after sampling was obtained as the average of several measurements, when observed variations were $<5 \%$.

After sampling, the filters were subjected to different types of analyses that allowed the inorganic and organic characterisation of total suspended particulate matter.

The determination of water soluble ions was carried out by ion chromatography (IC). The solution obtained after extraction with $20 \mathrm{~mL}$ of ultra-pure deionised water was filtered with PTFE syringe filter with a pore size of $0.45 \mu \mathrm{m}$ (VertiClean ${ }^{\mathrm{TM}}$ ) and subsequently analysed in a Thermo Scientific Dionex ${ }^{\mathrm{TM}}$ ICS-5000 Ion Chromatography. The filter extracts were analysed for $\mathrm{Cl}^{-}, \mathrm{NO}_{3}{ }^{-}, \mathrm{SO}_{4}{ }^{2-}, \mathrm{C}_{2} \mathrm{O}_{4}^{2-}, \mathrm{PO}_{4}{ }^{3-}, \mathrm{Na}^{+}, \mathrm{NH}_{4}{ }^{+}$, $\mathrm{K}^{+}, \mathrm{Mg}^{2+}$ and $\mathrm{Ca}^{2+}$. For anions, the following components were used: IonPac AS19 Capillary Column $(0.4 \times 250 \mathrm{~mm})$ in combination with the AG19 Guard Column $(0.4 \times 50 \mathrm{~mm})$, Anion Capillary Electrolytic Suppressor (ACESTM 300) and Eluent Generator Cartridges (EGC) for the generation of potassium hydroxide $(\mathrm{KOH})$ with concentrations between 2 and $50 \mathrm{mmol} \cdot \mathrm{L}^{-1}$. The runs lasted $30 \mathrm{~min}$ with a flow of $0.010 \mathrm{~mL} \cdot \mathrm{min}^{-1}$ and the following concentrations' slope: $0-10 \mathrm{~min}$ $\left(2-10 \mathrm{mmol} \cdot \mathrm{L}^{-1}\right) ; 10-20 \mathrm{~min}\left(10-45 \mathrm{mmol} \cdot \mathrm{L}^{-1}\right) ; 20-21 \mathrm{~min}$ $\left(45-50 \mathrm{mmol} \cdot \mathrm{L}^{-1}\right) ; 21-21.1 \mathrm{~min}\left(50-2 \mathrm{mmol} \cdot \mathrm{L}^{-1}\right)$ and $21.1-30 \mathrm{~min}$ $\left(2-2 \mathrm{mmol} \cdot \mathrm{L}^{-1}\right)$. For cations, the components were as follows: IonPac CS12A Capillary Column $(2 \times 250 \mathrm{~mm})$ in combination with the CG12A Guard Column $(2 \times 50 \mathrm{~mm})$, Cations Capillary Electrolytic Suppressor (CCES ${ }^{\text {тM }}$ 300) and Eluent Generator Cartridges (EGC) for the generation of methanesulfonic acid (MSA) at a concentration of $20 \mathrm{mmol} \cdot \mathrm{L}^{-1}$ and a flow of $0.25 \mathrm{~mL} \cdot \mathrm{min}^{-1}$ throughout the $17 \mathrm{~min}$ run. For both determinations, the injection was made by the Automatic Sampling System (Dionex AS-AP) with a high performance conductivity detector. Data were treated with the Chromeleon 6.8 software. For the equipment calibration, analytical curves were constructed for each of the ionic species, obtaining for each curve 7 concentration points (in triplicate) at the following concentrations: $0.2 ; 0.4 ; 0.6 ; 0.8 ; 1.0 ; 2.0$ e $3.0 \mathrm{mg} \cdot \mathrm{L}^{-1}$. The detection limits (of the mass of 8 blank filters) were estimated to be $0.17 \mu \mathrm{g} \cdot \mathrm{mL}^{-1}$ for $\mathrm{Na}^{+}, 0.01 \mu \mathrm{g} \cdot \mathrm{mL}^{-1}$ for $\mathrm{NH}_{4}^{+}$, $0.17 \mu \mathrm{g} \cdot \mathrm{mL}^{-1}$ for $\mathrm{K}^{+}, 0.01 \mu \mathrm{g} \cdot \mathrm{mL}^{-1}$ for $\mathrm{Mg}^{2+}, 0.07 \mu \mathrm{g} \cdot \mathrm{mL}^{-1}$ for $\mathrm{Ca}^{2+}$, $0.003 \mu \mathrm{g} \cdot \mathrm{mL}^{-1}$ for $\mathrm{Cl}^{-}, 0.03 \mu \mathrm{g} \cdot \mathrm{mL}^{-1}$ for $\mathrm{NO}_{3}^{-}, 0.33 \mu \mathrm{g} \cdot \mathrm{mL}^{-1}$ for $\mathrm{PO}_{4}^{3-}$, $0.11 \mu \mathrm{g} \cdot \mathrm{mL}^{-1}$ for $\mathrm{SO}_{4}^{2-}$ and $0.13 \mu \mathrm{g} \cdot \mathrm{mL}^{-1}$ for $\mathrm{C}_{2} \mathrm{O}_{4}^{2-}$.

Approximately $1 / 8$ of the filter was extracted to analyse elements by inductively coupled plasma mass spectrometry (ICP-MS) equipped with collision cell technology (CCT) (Xseries II-Thermo Scientific). The filters were extracted with a diluted acid solution $\left(\mathrm{HNO}_{3}, 1 \%\right)$, remaining for $5 \mathrm{~h}$ in a mechanical shaker ( $115 \mathrm{rpm}$ ) at room temperature, for a better removal of elements to the solution. Before ICP-MS analysis, the samples were filtered with PTFE syringe filters with a pore size of $0.45 \mu \mathrm{m}$ (VertiClean ${ }^{\mathrm{TM}}$ ). This analytical technique allowed the determination of 57 different elements, but only 13 elements were quantified in this study. The detection limits (of the mass of 8 blank filters) were estimated to be $0.4 \mathrm{ng} \cdot \mathrm{mL}^{-1}$ for $\mathrm{Al}, 9.0 \mathrm{ng} \cdot \mathrm{mL}^{-1}$ for $\mathrm{Ca}, 0.05 \mathrm{ng} \cdot \mathrm{mL}^{-1}$ for $\mathrm{Cu}, 29 \mathrm{ng} \cdot \mathrm{mL}^{-1}$ for $\mathrm{Fe}, 47 \mathrm{ng} \cdot \mathrm{mL}^{-1}$ for $\mathrm{K}$, $0.2 \mathrm{ng} \cdot \mathrm{mL}^{-1}$ for $\mathrm{Mg}, 0.03 \mathrm{ng} \cdot \mathrm{mL}^{-1}$ for $\mathrm{Mn}, 2.0 \mathrm{ng} \cdot \mathrm{mL}^{-1}$ for $\mathrm{Na}$, $0.002 \mathrm{ng} \cdot \mathrm{mL}^{-1}$ for $\mathrm{Pb}, 0.01 \mathrm{ng} \cdot \mathrm{mL}^{-1}$ for $\mathrm{Rb}, 0.009 \mathrm{ng} \cdot \mathrm{mL}^{-1}$ for $\mathrm{Sr}$, $0.08 \mathrm{ng} \cdot \mathrm{mL}^{-1}$ for Ti and $0.004 \mathrm{ng} \cdot \mathrm{mL}^{-1}$ for $\mathrm{Zn}$. The same analytical method has been previously applied to quartz filters for the determination of elements (Puxbaum et al., 2004; Vasconcellos et al., 2007). For quality control, all analyses were performed in triplicate (IC) and duplicate (ICP-MS). The blank values for ions and elements were subtracted from the sample results. For ions the uncertainties were in the range of $0.1-4.1 \%$. For elements the uncertainties were in the range of $0.5-4.9 \%$.
For the determination of the carbonaceous content, small discs with $9 \mathrm{~mm}$ diameter were punched out of the quartz fibre filters. The carbonaceous content (organic carbon (OC), elemental carbon (EC)) of particulate matter was measured with a homemade thermal-optical system, based on the thermal desorption/oxidation of particulate carbon to $\mathrm{CO}_{2}$, which is subsequently analysed by non-dispersive infrared (NDIR) $\mathrm{CO}_{2}$ analyser. Controlled heating in anoxic conditions was performed to separate $\mathrm{OC}$ into two fractions of increasing volatility. The first fraction corresponds to the volatilization at $T<200{ }^{\circ} \mathrm{C}$ of lower molecular weight organics $\left(\mathrm{OC}_{1}\right)$. The second fraction is related to decomposition and oxidation of higher molecular weight species at temperatures ranging from 200 to $600{ }^{\circ} \mathrm{C}\left(\mathrm{OC}_{2}\right)$. The last fraction of $\mathrm{OC}$ is identified by transmittance and corresponds to pyrolysed organic carbon (PC) produced in the previous heating steps. Separation between $\mathrm{OC}$ and EC was achieved by initially heating the filter punches under an inert atmosphere to evaporate first the OC fraction. The remaining fraction is sequentially evaporated/burnt under a gas flow containing $\mathrm{O}_{2}$. This last carbon fraction contains initial EC plus OC that has pyrolysed during heating under an inert atmosphere. The interference between PC and EC can be controlled by continuous evaluation of the blackening of filter using a laser beam and a photodetector measuring the filter light transmittance (Alves et al., 2011; Pio et al., 2011; Vicente et al., 2013).

TSP composite samples were subjected to detailed organic analysis by gas chromatography-mass spectrometry (GC-MS). Based on the determined OC content of collected samples, 3 to 4 consecutive filters were pooled, resulting in 4 sets of samples for each period studied (ALH1 to ALH4 - rainy season; ALS1 to ALS4 - dry season).The combined portions of the filters were consecutively extracted with dichloromethane and methanol (Fisher Scientific) and the total organic extract was separated into five different organic fractions by flash chromatography with activated silica gel and different solvents of increasing polarity. After elution, the obtained extracts were vacuum concentrated and evaporated to approximately $1 \mathrm{~mL}$ using a rotary evaporator and then dried under a gentle ultra-pure nitrogen flow. The description of the methodology for the organic compounds extraction can be found in Alves et al. (2011). The fractionated extracts were analysed with a Gas Chromatography model 6890, quadrupole Mass Spectrometry Detector 5973 from Hewlett Packard and with a Shimadzu QP5050A gas chromatography-mass spectrometer (GC-MS) with automatic injection. Before injection, the compounds with hydroxylic groups were converted into the corresponding trimethylsilyl derivatives by addition of $\mathrm{N}, \mathrm{O}$ bis(trimethylsilyl)triflouroacetamide (BSTFA): trimethylchlorosilane (TMCS) 99:1 (Supelco). The GC-MS calibration was performed with injection of about 110 standards in different concentration ranges and relative response factors calculated for each compound and for each organic class. For those with no authentic standards available, relative response factors were calculated as an average of the relative response factors from the overall homologous series or from compounds with similar chemical structure and retention time. Standards and samples were both co-injected with one internal standard: Tetracosane- $d_{50}$ (Sigma Aldrich). Compounds identification was based on comparison of resulting spectra with mass spectra libraries (Wiley 275 and NIST MS Search 2.0), co-injection with authentic standards and analysis of fragmentation patterns. The quantitative analysis was performed by both single ion monitoring (SIM) and total ion chromatogram (TIC) methods, in two separate GC runs. The blanks filters were analysed in the same way as for the samples and the data obtained were subtracted from the samples in order to obtain blank-corrected results. To test the recoveries, blanks filters previously spiked with five different known concentration ranges of representative organic standards were extracted and analysed. For the whole procedure (extraction and analysis), reproducible results of $95 \pm 3.9 \%$ and $96 \pm 5.8 \%$ were obtained for polar and non-polar compounds, respectively. In the case of levoglucosan, the extraction and fractionation procedure enabled a recovery of $91 \pm 11 \%$. The overall inaccuracy of the calibration procedure did not 
exceed $14 \%$ for the aliphatic fraction, $15 \%$ for polycyclic aromatic compounds, $15 \%$ for acids and $12 \%$ for sugars.

\section{Results and discussion}

\subsection{Meteorological conditions and air mass trajectories}

The Alenquer region, due to its location, has equatorial climate, which is characterised as hot and humid, characteristic of Tropical Forests, not subject to significant changes in temperature. The temperature, relative humidity and precipitation mean values obtained during the rainy season campaign were $26.8{ }^{\circ} \mathrm{C}, 80 \%$ and $12 \mathrm{~mm}$, respectively. The rainiest days were 25 and 27 April with $44 \mathrm{~mm}$ and $35 \mathrm{~mm}$, respectively. During the dry season campaign the mean values obtained for temperature, relative humidity and precipitation were $27.4{ }^{\circ} \mathrm{C}, 69 \%$ and $2 \mathrm{~mm}$, respectively. The rainiest day was 30 August with $15 \mathrm{~mm}$. Two tables with complete data for meteorological parameters are attached as supplementary material (Tables $1 \mathrm{~S}$ and $2 \mathrm{~S}$ ). The sampling place shows low anthropogenic influence coming from Alenquer, because the prevailing wind, SE-E, reaches the sampling site before reaching the city. Backward trajectory cluster analysis was carried out by using the HYSPLIT model. The 10 days ( $240 \mathrm{~h}$ ) backward trajectories were clustered after calculation. Each cluster is formed by similar trajectories and represents a possible pattern of air-mass behaviour over the studied area. The details of the programme are given in Draxler (1999). Fig. 2 shows the average trajectories of the four clusters retained for the two studied seasons. During the rainy season, the Alenquer region was mostly affected by air masses with Atlantic origin (96\% of backward trajectories) that develop along the Amazon River (Fig. 2a). According to Fig. 2b, during the dry season the situation was quite different, with most of the backward trajectories passing through several northern states of Brazil, before arriving at the study site.

\subsection{Total suspended particulate matter and carbonaceous content}

TSP concentrations varied between 12 and $17 \mu \mathrm{g} \cdot \mathrm{m}^{-3}$ and between 16 and $43 \mu \mathrm{g} \cdot \mathrm{m}^{-3}$, in the rainy and dry season, respectively. A substantially higher mean concentration $\left(31 \pm 7.8 \mu \mathrm{g} \cdot \mathrm{m}^{-3}\right)$ was obtained for the dry season in comparison with the wet season $\left(14 \pm 1.3 \mu \mathrm{g} \cdot \mathrm{m}^{-3}\right)$ (Fig. 3).

The carbonaceous content $(\mathrm{TC}=\mathrm{OC}+\mathrm{EC}$ ) represented, on average, approximately $27 \%$ and $21 \%$ of the particulate matter in the rainy and dry season, respectively (Fig. 3 ). In the rainy season, the OC concentrations varied between 2.2 and $4.7 \mu \mathrm{g} \cdot \mathrm{m}^{-3}$, with an average of $3.3 \pm 0.63 \mu \mathrm{g} \cdot \mathrm{m}^{-3}$, whilst EC presented values between 0.21 and $0.58 \mu \mathrm{g} \cdot \mathrm{m}^{-3}$, averaging $0.37 \pm 0.10 \mu \mathrm{g} \cdot \mathrm{m}^{-3}$. In the dry season, the OC concentrations varied between 3.5 and $10 \mu \mathrm{g} \cdot \mathrm{m}^{-3}$, with an average of $5.5 \pm 2.2 \mu \mathrm{g} \cdot \mathrm{m}^{-3}$. EC varied between 0.40 and $2.03 \mu \mathrm{g} \cdot \mathrm{m}^{-3}$, averaging $0.96 \pm 0.50 \mu \mathrm{g} \cdot \mathrm{m}^{-3}$. The origin of carbonaceous particles can be assigned on the basis of the relation between OC and EC. Since EC is predominately emitted from primary combustion sources, it has often been used as a tracer to estimate primary OC (Cao et al., 2004). High OC-EC correlations $\left(R^{2}=0.89\right)$ (Fig. 1Sb)) in dry season indicates that the relative rates of EC and OC emission would be proportional to each other and common sources and transport processes for both carbonaceous species. The very weak correlation between $O C$ and EC $\left(R^{2}=0.07\right)$ (Fig. 1Sa)) in the rainy season, suggests that OC and EC fractions were not contributed by a single primary source rather could be related to multiple sources, and a dissimilar influence of meteorological factors on the two carbonaceous constituents (Kumar and Yadav, 2016). OC/EC ratios exceeding 2.0 have been used to identify secondary organic aerosol (SOA) formation by chemical reactions in the atmosphere (Alves et al., 2007). During the rainy season, OC/EC ratios ranged from 6 to 15, with an overall average of 9 . In the dry season, OC/EC ratios ranged between 4 and 9 , averaging 6.

TSP, OC and EC average concentrations from this study are compared in Table 3S (table with more complete data attached as supplementary material) with those from other studies made in the Amazon basin. It is necessary to note that in addition to variations in the concentration values from place to place; different sampling techniques and analytical methods can lead to some disparities.

The TSP levels are comparable to those described by Martin et al. (2010), for the Santarem region, mean values between 2 and $10 \mu \mathrm{g} \cdot \mathrm{m}^{-3}$ for the fine and coarse fractions and between 25 and $40 \mu \mathrm{g} \cdot \mathrm{m}^{-3}$ for the fine and coarse fractions, for rainy and dry season,
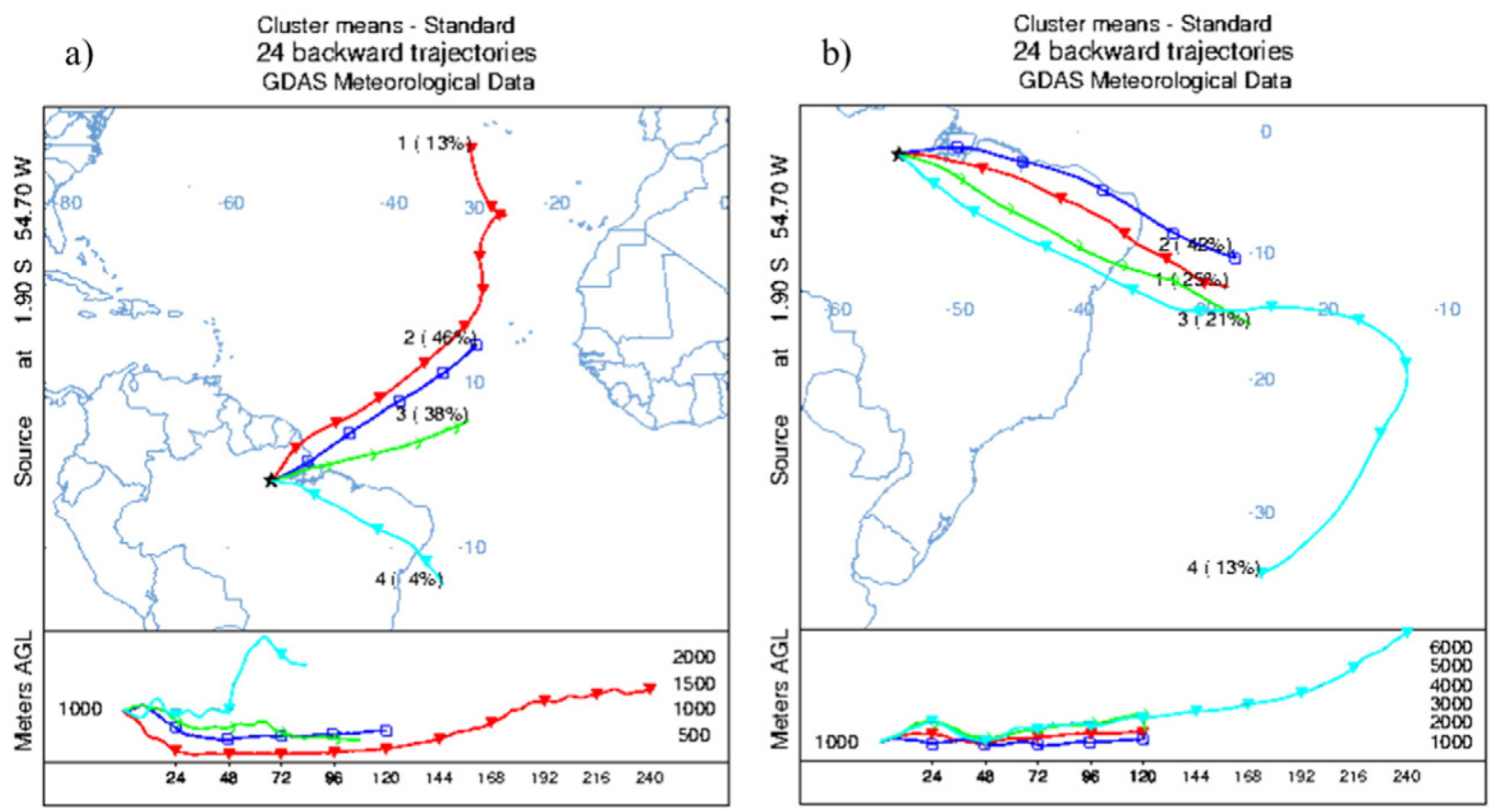

Fig. 2. HYSPLIT model backward trajectories arriving at Alenquer area in two different periods, rainy season (Fig. 2a) and dry season (Fig. 2b). 

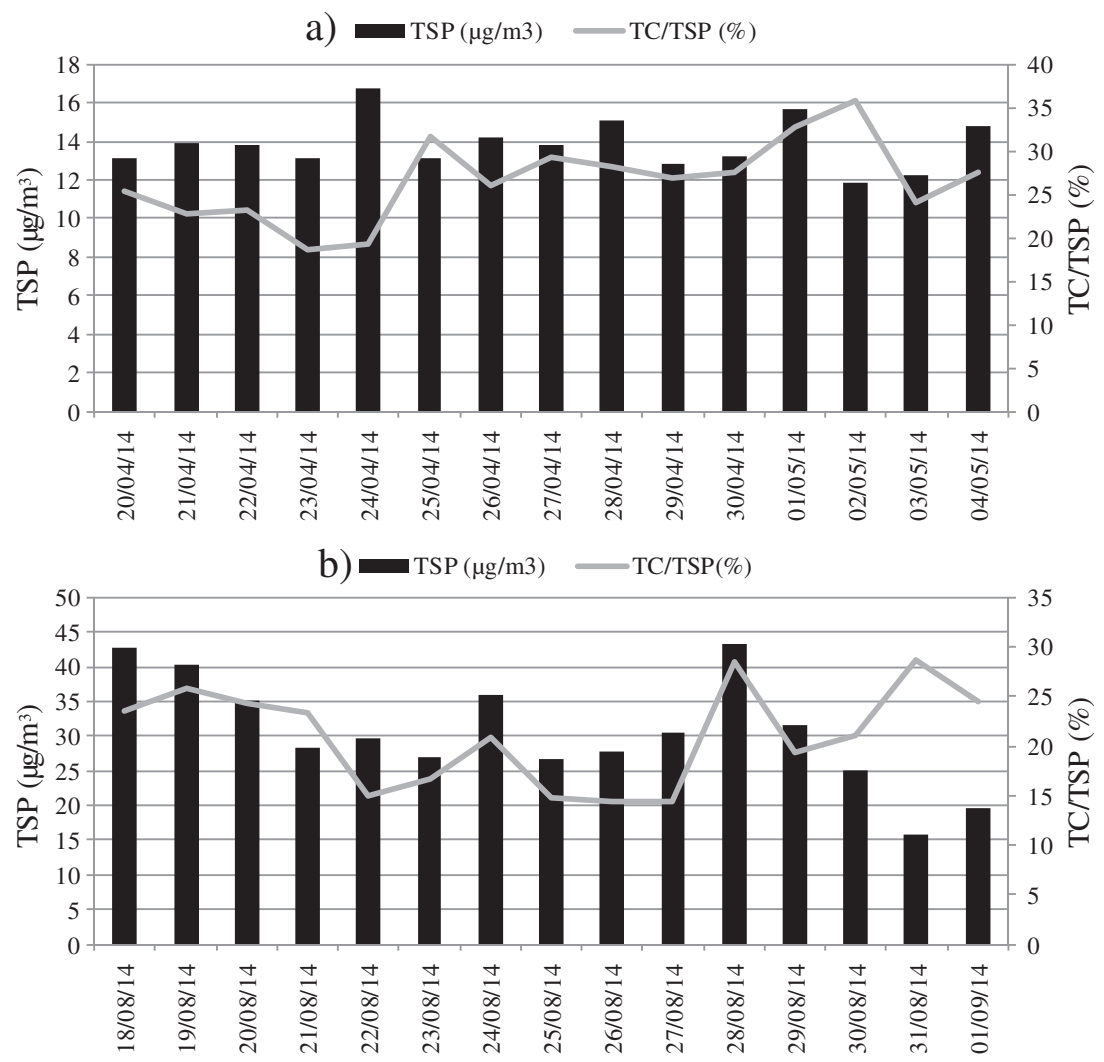

Fig. 3. Variation of aerosol mass and percentage of total carbon in TSP, rainy season (Fig. 3a) and dry season (Fig. 3b).

respectively (Table $3 \mathrm{~S}$ ). The TSP values are also in accordance with the data described by Formenti et al. (2001) for Balbina region during the so-called "dusty period". During the rainy season (DecemberAbril), the Intertropical Convergence Zone (ITCZ) (i.e., the confluence between the northeastern and southeastern trade winds extending from West Africa to South America) has an important influence in the northern and central Amazonia. Mineral dust and biomass burning particles from Africa reach the northern coast of South America when the ITCZ is located to the south of the equator between December and Abril (Formenti et al., 2001; Swap et al., 1992). During those periods, in Balbina, mean values between 8.4 and $18 \mu \mathrm{g} \cdot \mathrm{m}^{-3}$ for the fine and coarse particle fractions were, respectively, were registered (Formenti et al., 2001).

The carbonaceous content in the Alenquer particulate matter is higher than values observed in central Amazonia (Balbina), regardless of the season, and also than values observed in southern Amazonia (Fazenda Nossa Senhora Aparecida and Reserva Biológica Jarú) during the rainy season (Table 3S). These facts may be related with the longdistance transport and with the burning episodes which affect the study area.

\subsection{Inorganic speciation of total particulate matter}

The average concentrations of water-soluble ions for rainy and dry season are presented in Table 1. Tables with complete data are attached as supplementary material (Tables $4 \mathrm{~S}$ and $5 \mathrm{~S}$ ). The ionic balance was calculated to assess the quality of the data. In both campaigns $70 \%$ of the samples showed satisfactory values. Satisfactory values correspond to a variation within $\pm 10 \%$ range (Feitosa and Manoel Filho, 1997). In analytical terms, this indicates that the data are reliable. The watersoluble ions accounted for about 3 to $14 \%$ of the concentration of TSP, with an average of $7 \%$, during the rainy season. In the dry season they represent about 7 to $32 \%$ of TSP, averaging $18 \%$. In the rainy season the dominant ions were $\mathrm{SO}_{4}^{2-}, \mathrm{Na}^{+}, \mathrm{NO}_{3}^{-}, \mathrm{C}_{2} \mathrm{O}_{4}^{2-}$ and $\mathrm{Cl}^{-}$. In the dry season, there was an average concentrations increase of all ions, but especially the $\mathrm{Mg}^{2+}, \mathrm{Na}^{+}, \mathrm{Cl}^{-}$and $\mathrm{SO}_{4}^{2-}$ (Table 1).

In the rainy season, the $\mathrm{Na}^{+}, \mathrm{Cl}^{-}$and $\mathrm{Mg}^{2+}$ were strongly correlated $\left(\mathrm{R}^{2}>0.90\right)$ indicating the same emission source. The average ratio $\mathrm{Na}^{+} /$ $\mathrm{Cl}^{-}$of 1.3 is within the typical range (0.5-1.5) (Chesselet et al., 1972) associated with a marine source. In the dry season, the $\mathrm{Na}^{+}$and $\mathrm{Cl}^{-}$remain well correlated $\left(\mathrm{R}^{2}=0.91\right)$, but the average ratio $\mathrm{Na}^{+} / \mathrm{Cl}^{-}=3$ is out of this range, indicating an enrichment of $\mathrm{Na}^{+}$, probably from soil. In the rainy season, secondary species, such as $\mathrm{SO}_{4}^{2-}$ and $\mathrm{NO}_{3}^{-}$resulting from the oxidation of $\mathrm{SO}_{2}$ and $\mathrm{NO}$ emissions, exhibit a good correlation $\left(\mathrm{R}^{2}=0.83\right)$. In the dry season, the $\mathrm{NO}_{3}^{-}$and $\mathrm{SO}_{4}^{2-}$ have lower correlation with each other $\left(R^{2}=0.74\right)$, which may indicate different origins other than the marine. The $\mathrm{K}^{+}$average concentration increased from $120 \mathrm{ng} \cdot \mathrm{m}^{-3}$ in the rainy season to $340 \mathrm{ng} \cdot \mathrm{m}^{-3}$ in the dry season. Since the studied region is strongly affected by marine aerosol, especially in the rainy season, and the sea salts are one of the main contributors to ionic species, the input from other sources excluding marine aerosol can be estimated, using the concentrations of non-sea-salt-potassium

Table 1

Average concentration and standard deviations for water-soluble ions by season.

\begin{tabular}{lll}
\hline Water-soluble ions $\left(\mathrm{ng} \cdot \mathrm{m}^{-3}\right)$ & Rainy season $(n=15)$ & Dry season $(n=15)$ \\
\hline $\mathrm{Na}^{+}$ & $142 \pm 126$ & $1267 \pm 822$ \\
$\mathrm{NH}_{4}^{+}$ & n.d. & $63 \pm 45$ \\
$\mathrm{~K}^{+}$ & $120 \pm 26$ & $340 \pm 115$ \\
$\mathrm{Mg}^{2+}$ & $24 \pm 14$ & $222 \pm 68$ \\
$\mathrm{Ca}^{2+}$ & $45 \pm 41$ & $161 \pm 92$ \\
$\mathrm{Cl}^{-}$ & $127 \pm 135$ & $954 \pm 1020$ \\
$\mathrm{NO}_{3}^{-}$ & $139 \pm 81$ & $1004 \pm 437$ \\
$\mathrm{SO}_{4}^{2-}$ & $173 \pm 105$ & $1256 \pm 422$ \\
$\mathrm{C}_{2} \mathrm{O}_{4}^{2-}$ & $139 \pm 13$ & n.d. \\
$\mathrm{PO}_{4}^{3-}$ & $43 \pm 37$ & $256 \pm 165$ \\
\hline
\end{tabular}

n.d. - not detected. 
(nss- $\mathrm{K}^{+}$) and non-sea-salt-sulphate (nss- $\mathrm{SO}_{4}^{2-}$ ) as expressed by the following formulas: $\mathrm{C}_{\mathrm{nss}-\mathrm{K}}^{+}=\mathrm{C}_{\mathrm{K}}^{+}-0.0355 * \mathrm{C}_{\mathrm{Na}}^{+}$and $\mathrm{C}_{\mathrm{nss}-\mathrm{SO} 4}^{2}{ }^{-}=$ $\mathrm{C}_{\mathrm{SO} 4}^{2-}-0.2455 * \mathrm{C}_{\mathrm{Na}}^{+}$(Lai et al., 2007). High ratios of nss-SO ${ }_{4}^{2-}$ to $\mathrm{SO}_{4}^{2-}$ (82\% - rainy season; $76 \%$ - dry season) suggest that sea salt was not the main carrier of particulate sulphate in both seasons. Furthermore, the very high ratios of $n s s-\mathrm{K}^{+} / \mathrm{K}^{+}(96 \%$ - rainy season; $85 \%$ - dry season) are likely associated with other emissions, such as biomass burning, instead of sea salt contribution. This hypothesis is supported by the reasonable correlation observed between nss- $\mathrm{K}^{+}$ and OC $\left(R^{2}=0.44\right.$ - rainy season; $R^{2}=0.47$ - dry season) (Fig. 2Sa) and $b$ )) indicating that a substantial part of $\mathrm{OC}$ is from biomass burning. The average $\mathrm{K}^{+} / \mathrm{OC}$ ratios in Alenquer varied from 0.04 to 0.06 in the rainy and dry seasons, respectively. These ratios are comparable to those calculated from emission factors reported by Andreae and Merlet (2001) for tropical forest (average 0.06).

Although in the wet season large wildfire events are not expected, small scale burnings are likely to occur. In the dry season, the sulphate mean concentration is higher due to much less wet scavenging, as well as to the biomass burning particles from nearly 4474 forest fires in the Pará state and in the other large states (Maranhão, Tocantins, Bahia, Piauí and Ceará), whose plumes may have somehow reached the Alenquer sampling site (INPE, 2015) (Fig. 2b).

$\mathrm{NH}_{4}^{+} /\left(\mathrm{NO}_{3}^{-}+\mathrm{SO}_{4}^{2-}\right)$ lower than 0.5 in both seasons indicate that $\mathrm{HNO}_{3}$ and $\mathrm{H}_{2} \mathrm{SO}_{4}$ cannot be fully neutralised by ammonia. Neutralisation is mainly performed by mineral aerosols coming from soil. In the dry season, $\mathrm{Ca}^{2+}$ and $\mathrm{Mg}^{2+}$ do not correlate, probably due to the fact that $\mathrm{Mg}^{2+}$ is in part coming from sea salt and not entirely from soil. This assumption is corroborated by the reasonable correlation between $\mathrm{Mg}^{2+}$ and $\mathrm{Cl}^{-}\left(\mathrm{R}^{2}=0.58\right)$ (Fig. 3Sa)). Although $\mathrm{Ca}^{2+}$ may be partially associated with marine aerosols, the lack of correlation with both $\mathrm{Na}^{+}$and $\mathrm{Cl}^{-}$suggest a major origin in soil.

The average concentrations of principal elements for rainy and dry season are presented in Table 2. Tables with complete data are attached as supplementary material (Tables $6 \mathrm{~S}$ and $7 \mathrm{~S}$ ).

With regard to the mean concentrations of elements, $\mathrm{Na}, \mathrm{Ca}$ and $\mathrm{K}$ were predominant, in the rainy season. Except for $\mathrm{Cu}$ and $\mathrm{Zn}$, in the dry season, in general, increased concentrations of all elements were observed, especially for $\mathrm{Mn}, \mathrm{Fe}$ and $\mathrm{Mg}$. The $\mathrm{Ca}$ (rainy season: $229 \mathrm{ng} \cdot \mathrm{m}^{-3}$; dry season: $209 \mathrm{ng} \cdot \mathrm{m}^{-3}$ ) and $\mathrm{Cu}$ (rainy season: $96 \mathrm{ng} \cdot \mathrm{m}^{-3}$; dry season: $89 \mathrm{ng} \cdot \mathrm{m}^{-3}$ ) mean concentrations do not show any seasonal trend. Regarding $\mathrm{Ca}$, it could not be established correlations with any other element to explain its origin. Its constant presence in the two seasons may be justified because it is a natural element from the soil. Copper was detected at appreciable amounts. Although it has been pointed out as a good tracer in urban environments for non-exhaust vehicle emissions (Alves et al., 2015; Calvo et al., 2013), Cu has been identified as biogenic aerosol in Amazonia (Guyon et al., 2003). In this study, the Cu high concentrations observed in can be justified with the use of soil correction products. As observed

Table 2

Average concentration and standard deviations for principal elements by season.

\begin{tabular}{lll}
\hline Elements $\left(\mathrm{ng} \cdot \mathrm{m}^{-3}\right)$ & Rainy season $(n=15)$ & Dry season $(n=15)$ \\
\hline $\mathrm{Al}$ & $18 \pm 8.6$ & $34 \pm 13$ \\
$\mathrm{Ca}$ & $229 \pm 77$ & $209 \pm 66$ \\
$\mathrm{Cu}$ & $96 \pm 30$ & $89 \pm 32$ \\
$\mathrm{Fe}$ & $7.0 \pm 4.0$ & $32 \pm 15$ \\
$\mathrm{~K}$ & $111 \pm 20$ & $289 \pm 85$ \\
$\mathrm{Mg}$ & $43 \pm 15$ & $133 \pm 63$ \\
$\mathrm{Mn}$ & $1.2 \pm 0.55$ & $6.4 \pm 3.6$ \\
$\mathrm{Na}$ & $387 \pm 129$ & $1040 \pm 648$ \\
$\mathrm{~Pb}$ & $0.21 \pm 0.05$ & $0.51 \pm 0.15$ \\
$\mathrm{Rb}$ & $0.27 \pm 0.04$ & $0.72 \pm 0.29$ \\
$\mathrm{Sr}$ & $0.55 \pm 0.19$ & $1.2 \pm 0.42$ \\
$\mathrm{Ti}$ & n.d. & $0.25 \pm 0.07$ \\
$\mathrm{Zn}$ & $3.8 \pm 1.7$ & n.d. \\
\hline
\end{tabular}

n.d. - not detected. for the corresponding water soluble ions, $\mathrm{Na}$ and $\mathrm{Mg}$ were strongly correlated in rainy $\left(\mathrm{R}^{2}=0.95\right)$ and dry $\left(\mathrm{R}^{2}=0.98\right)$ season (Fig. 4Sa) and $\mathrm{b})$ ). In general, the individual elemental concentrations obtained in this study are quite comparable to the values reported by Artaxo et al. (1988, 1990), as well as those from Formenti et al. (2001) for dry and rainy season background aerosol in the north area of the Amazon basin, although some differences were found in the levels of $\mathrm{Ca}, \mathrm{K}$, $\mathrm{Na}$. The soil observed in the study region is the varzea type. According to Konhauser et al. (1994) the only nutrient-rich soils in Amazonia. Compared to other Amazonia regions, these soils show the highest cation to silica ratios, with the concentration of $\mathrm{Ti}, \mathrm{Mn}, \mathrm{Mg}, \mathrm{Ca}, \mathrm{K}, \mathrm{P}$ and $\mathrm{Na}$ most closely approaching crustal abundance (Konhauser et al., 1994). Based on this information and in the enrichment factors calculation (not shown in the article) it is noticed that there will be other sources for certain elements.

\subsection{Organic speciation of total particulate matter}

The organic fraction of the carbonaceous aerosol is formed by a complex mixture of compounds, which can be grouped into classes such as $n$-alkanes, $n$-alkenes, polycyclic aromatic hydrocarbons (PAH), nalkanols, $n$-alkanals, hydroxyl compounds, $n$-alkanoic acids, sugars and other non-linear compounds. In this study, attention was focused on $n$-alkanes, $n$-alkenes, PAH, $n$-alkanoic acids and $n$-alkenoic acids. The identification and quantification of some of these species associated with the application of diagnostic parameters, such as carbon preference index (CPI), average chain length (ACL) and chain-length ratios, supply data that can help to assign sources or atmospheric processes. For $n$-alkanes, the CPI is expressed as a sum of the odd carbon number homologs, over a range, divided by a sum of even carbon homologs, over the same range. For $n$-alkanoic acids, CPI is calculated inverting the ratio to have even-to-odd homologs. Splitting the $\mathrm{CPI}$ range, the microbial contributions $\left(\mathrm{C}_{10}\right.$ to $\left.\mathrm{C}_{24}\right)$ can be distinguished from the higher plant wax inputs $\left(C_{22}\right.$ to $\left.C_{34}\right)$, for example. The ACL is calculated as an average number of carbon atoms per molecule based on the abundance of the odd or even high homologs (Alves, 2008). Table with complete organic classes data is attached as supplementary material (Table $8 \mathrm{~S}$ ).

The $n$-alkane total concentrations varied from 7 to $12 \mathrm{ng} \cdot \mathrm{m}^{-3}$, with an average of $9 \mathrm{ng} \cdot \mathrm{m}^{-3}$ and from 5 to $35 \mathrm{ng} \cdot \mathrm{m}^{-3}$, with an average of $15 \mathrm{ng} \cdot \mathrm{m}^{-3}$, in the rainy and dry seasons, respectively (Fig. 4).

These levels are lower than those measured, during the dry season, in the Alta Floresta (South area of the Amazon basin) $\left(12-238 \mathrm{ng} \cdot \mathrm{m}^{-3}\right.$; average $\left.=68 \mathrm{ng} \cdot \mathrm{m}^{-3}\right)$ by Vasconcellos et al. (1998), and in the Ducke Forest Reserve (North area of the Amazon basin) $\left(260-810 \mathrm{ng} \cdot \mathrm{m}^{-3}\right.$; average $=422 \mathrm{ng} \cdot \mathrm{m}^{-3}$ by Simoneit et al. (1990). This comparison is also temporal once the latter study was made over 20 years ago. The $n$-alkane series comprised the homologues from $C_{11}$ to $C_{38}$, with an odd carbon number predominance and maximising for the homologues $\geq C_{23}$ (Fig. 4), in both seasons studied. Long chain $n$-alkanes $\left(C_{21}-C_{37}\right)$, are synthesised as part of the epicuticular leaf wax of terrestrial plants and are among the most recognisable and widely used plant biomarkers. Plants typically produce a range of $n$-alkanes, commonly with a strong odd-over-even predominance and one or two dominant chain lengths (Abas and Simoneit, 1996, 1997; Alves, 2008; Bush and McInerney, 2013). In this study, the two dominant $n$-alkanes $\left(C_{\max }\right)$ were $C_{29}$ and $C_{31}$, in both seasons. The ratio between these two homologues remained approximately constant over the observation period (Table 3), suggesting a constancy in the typology of wax $n$-alkane emissions along the two studied seasons. The ACL values of $n$-alkanes also presented a regular behaviour along the two seasons.

The CPI average for the whole range of $n$-alkanes varied from 1.4 in the rainy season and 3 in the dry season (Fig. 4). CPI values near unity, as observed in the rainy season, have been pointed out as indicative of anthropogenic inputs, such as emissions from incomplete combustion of fossil fuels (Alves, 2008). On the other hand, values near or $>3$, as 

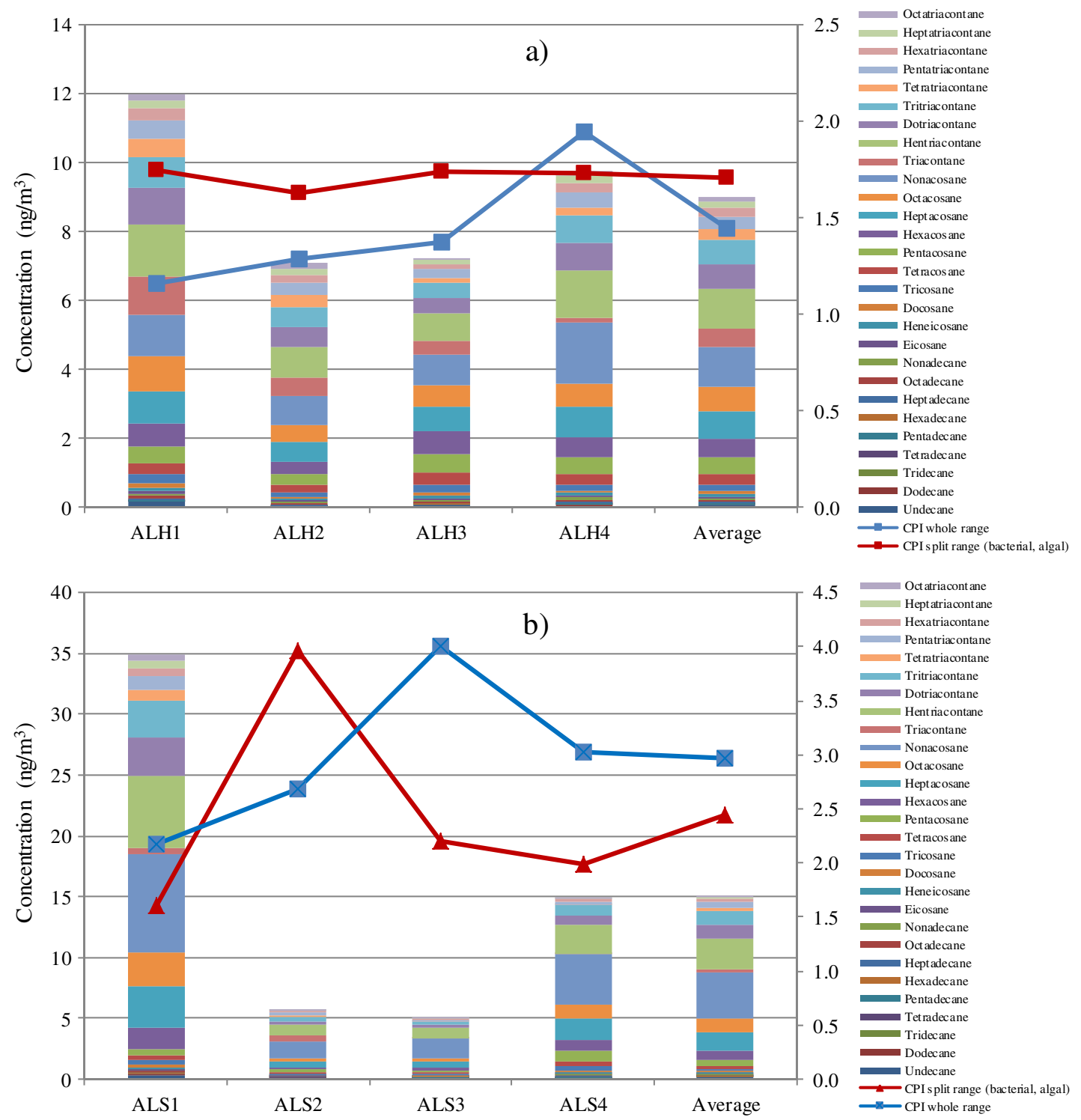

Fig. 4. Seasonal variation of $n$-alkanes concentration and CPI indexes in the rainy season (Fig. 4a) and dry season (Fig. 4b). ALH1 - 20 to 23/04/14; ALH2 - 24 to 27/04/14; ALH3 - 28/04 to 01/05/14; ALH4 - 02 to 04/05/14; ALS1 - 18 to 21/08/14; ALS2 - 22 to 25/08/14; ALS3 - 26 to 29/08/14; and ALS4 - 30/08 to 01/09/14.

verified in the dry season, indicate that the $n$-alkanes are predominantly from terrestrial higher plant waxes.

Due to the permanent wet scavenging processes, the $n$-alkanes concentration along the rainy season is much more constant than in the dry season. In the dry season, one set of samples (ALS1) is noteworthy for

Table 3

Ratios and other parameters calculated with homologous compound series of organic compounds.

\begin{tabular}{|c|c|c|c|c|}
\hline \multirow[t]{2}{*}{ Ratios } & \multicolumn{2}{|l|}{ Range } & \multicolumn{2}{|c|}{ Average } \\
\hline & $\begin{array}{l}\text { Rainy } \\
\text { season }\end{array}$ & Dry season & $\begin{array}{l}\text { Rainy } \\
\text { season }\end{array}$ & $\begin{array}{l}\text { Dry } \\
\text { season }\end{array}$ \\
\hline n-Alkane $C_{\max }$ & $C_{29}, C_{31}$ & $C_{29}, C_{31}$ & & \\
\hline n-Alkene $C_{\max }$ & $\mathrm{C}_{21}$ & $\mathrm{C}_{25}$ & & \\
\hline$n$-Alkane $C_{31} /\left(C_{31}+C_{29}\right)$ & $0.44-0.56$ & $0.33-0.42$ & 0.49 & 0.38 \\
\hline n-Alkane CPI (whole range) & $1.2-1.9$ & $2.2-4.0$ & 1.4 & 3.0 \\
\hline$n$-Alkanoic acids $C_{\max }$ & $\mathrm{C}_{10}$ & $\mathrm{C}_{16}$ & & \\
\hline$n$-Alkanoic acid $>C_{22} /<C_{20}$ & $\ldots-0.013$ & $0.015-0.028$ & 0.007 & 0.021 \\
\hline n-Alkanoic acid CPI (whole range) & $1.2-2.6$ & $8.6-13$ & 1.8 & 10 \\
\hline ACL $n$-alkanes & $28.9-29.8$ & $29.1-29.8$ & 29.5 & 29.5 \\
\hline ACL $n$-alkanoic acid & $22.4-22.5$ & $22.7-23.5$ & 22.5 & 23.3 \\
\hline
\end{tabular}

having concentrations substantially higher than the others. This peak is likely of local anthropogenic origin, since they correspond to the minimum values of the global CPI. Even in the dry season, the CPI for microbial contributions shows a peak for the ALS2 set, suggesting that during those days there was a greater contribution of this nature.

The aliphatic fraction also contains $n$-alkenes. The $n$-alkene total concentrations varied from 0.15 to $0.90 \mathrm{ng} \cdot \mathrm{m}^{-3}$, with an average of $0.47 \mathrm{ng} \cdot \mathrm{m}^{-3}$ and from 0.42 to $2.5 \mathrm{ng} \cdot \mathrm{m}^{-3}$, with an average of $1.1 \mathrm{ng} \cdot \mathrm{m}^{-3}$, in the rainy and dry seasons, respectively. The $n$-alkenes series comprised homologues from $C_{12}$ to $C_{28}$, with an even carbon number predominance along the two studied seasons. The two dominant $n$-alkenes $\left(C_{\max }\right)$ were $C_{21}$ and $C_{25}$, in the rainy and dry seasons respectively. $n$-Alkenes are constituents of gasoline fuels, motor vehicle exhaust emissions and biomass fuel. The presence of these compounds in atmospheric particulate may be related to the way energy is produced in the region. The electric power is generated by diesel fuel combustion in thermoelectric powerplant.

$\mathrm{PAH}$ are one of the organic compound classes most studied due to its carcinogenic and mutagenic characteristics. PAH are generated from fossil fuels and from primary products of incomplete combustion of organic materials (Rogge et al., 1993a; Schauer et al., 1996). The total 

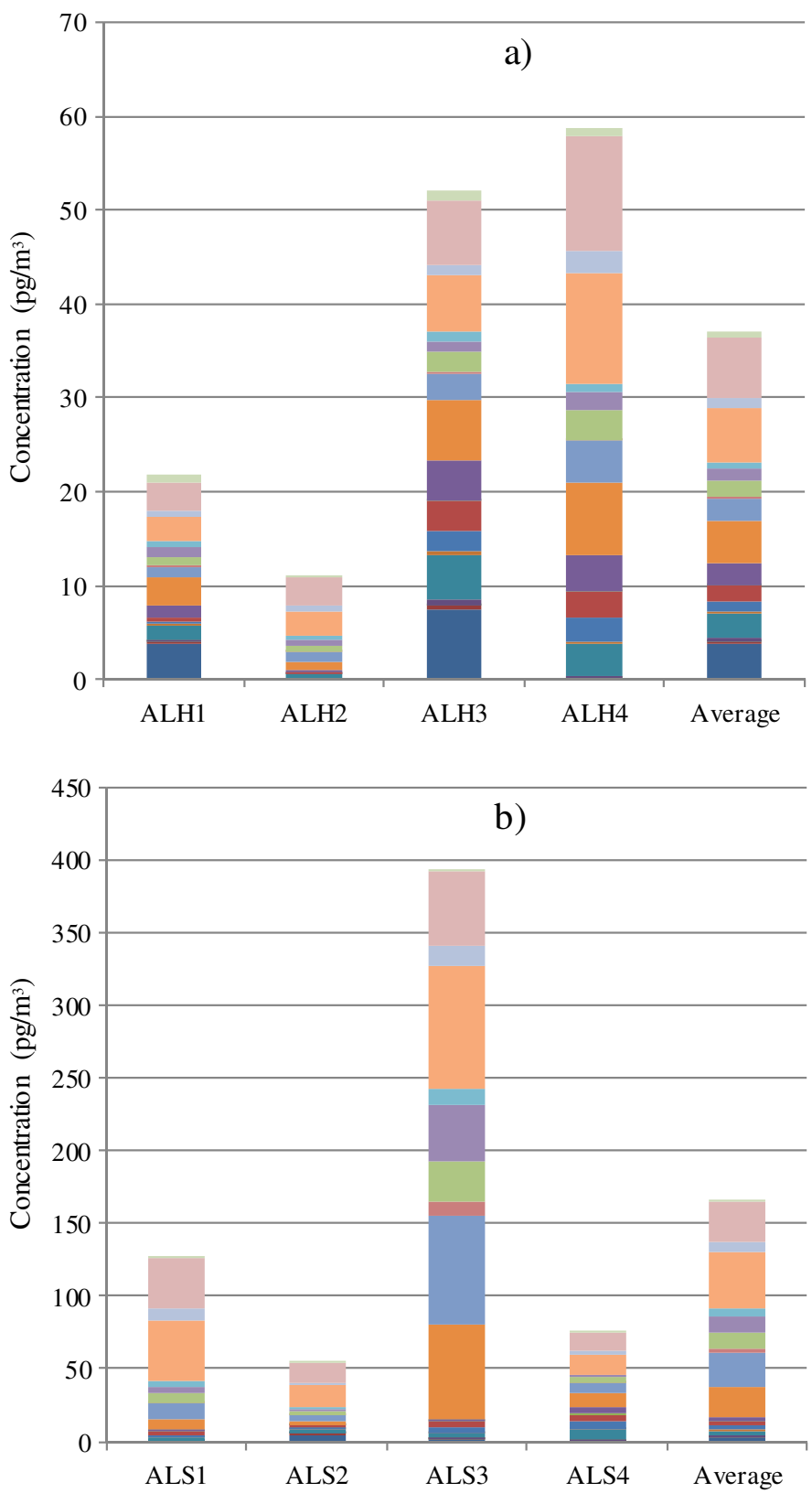

Coronene

Benzo[g,h,i] perylene

Dibenzo[a,h] anthrace ne

Inde no[1,2,3-cd]pyrene

- Perylene

- Benzo[a]pyrene

- Benzo[e]pyrene

- Benzo[k]fluoranthene

- Benzo $[\mathrm{b}+\mathrm{j}]$ fluoranthene

- Chrysene

- Benzo[a]anthracene

- Retene

- p-Terphenyl

- Pyrene

Fluoranthene

- Anthracene

- Phenanthrene

- Fluorene

- Acenaphthene

- Acenaphthylene

- Naphtha lene

Coronene

- Benzo[g,h,i]pery lene

Dibenzo[a,h]anthracene

- Indeno[1,2,3-cd]pyrene

- Perylene

- Benzo[a]pyrene

- Benzo[e]pyrene

- Benzo[k]fluoranthene

- Benzo[b+j]fluoranthene

- Chrysene

- Benzo[a]anthracene

- Retene

- $\mathrm{p}$-Terphenyl

- Pyrene

- Fluoranthene

- Anthracene

- Phenanthrene

- Fluorene

- Acenaphthene

- Acenaphthylene

- Naphthalene

Fig. 5. Seasonal variation of PAH concentration in the rainy season (Fig. 5a) and dry season (Fig. 5b).

concentrations varied from 11 to $59 \mathrm{pg} \cdot \mathrm{m}^{-3}$, with an average of $36 \mathrm{pg} \cdot \mathrm{m}^{-3}$ and from 54 to $393 \mathrm{pg} \cdot \mathrm{m}^{-3}$, with an average of $162 \mathrm{pg} \cdot \mathrm{m}^{-3}$, in the rainy and dry seasons, respectively (Fig. 5). The four most abundant PAH detected in both studied seasons were benzo[g,h,i]perylene (rainy season - $25 \mathrm{pg} \cdot \mathrm{m}^{-3}$; dry season $-113 \mathrm{pg} \cdot \mathrm{m}^{-3}$ ), indeno[1,2,3-cd]pyrene (rainy season $-23 \mathrm{pg} \cdot \mathrm{m}^{-3}$; dry season $-153 \mathrm{pg} \cdot \mathrm{m}^{-3}$ ), chrysene (rainy season $-18 \mathrm{pg} \cdot \mathrm{m}^{-3}$; dry season $-85 \mathrm{pg} \cdot \mathrm{m}^{-3}$ ) and benzo[b $\left.+\mathrm{j}\right]$ fluoranthene (rainy season $9.5 \mathrm{pg} \cdot \mathrm{m}^{-3}$; dry season $-96 \mathrm{pg} \cdot \mathrm{m}^{-3}$ ). It is observed that in the dry season the concentrations of those PAH were significantly higher. Typically, the background concentrations of PAH reported for remote locations have 1-2 times smaller magnitude compared to urban areas (Halsall et al., 1997). In Alenquer, PAH were found in all samples, but at low concentrations, typical of remote locations.

Comparing remote site samples with urban samples, the ratio benzo[e]pyrene/benzo[a]pyrene is important. The ratio is close to unity from gasoline, diesel fuel and burning oil emissions. In the particulate matter collected in this study, these ratios were 1.3 and 2.4 in the rainy and dry seasons, respectively. It can be assumed that these reasons in the dry season are high due to biomass burning.

These levels are lower than those measured, during the dry season, in Alta Floresta (South area of the Amazon basin) (13$9866 \mathrm{pg} \cdot \mathrm{m}^{-3}$; average $=3334 \mathrm{pg} \cdot \mathrm{m}^{-3}$ ) by Vasconcellos et al. (1998). The six most abundant PAH detected in Alta Floresta were benzo[b $+\mathrm{j}+\mathrm{k}$ ]fluoranthene, benzo[e]pyrene, benzo[g,h,i] perylene, indeno[1,2,3-cd]pyrene, chrysene and benzo[a]pyrene. They are also lower than the values described by Krauss et al. (2005), for the Manaus secondary forest region, during the dry season. On the other hand, Simoneit et al. (1990), in the studies developed in the Duck Forest Reserve region, during the dry season (North area of the Amazon basin) found PAH only at trace levels.

$n$-Alkanoic acids constitute another group of solvent-extractable compounds present in the Alenquer aerosol samples. The $n$-alkanoic acids distribution $\left(\mathrm{C}_{8}-\mathrm{C}_{26}\right)$ is characterised by an even carbon number 
preference, in both seasons. The $n$-alkanoic acids total concentrations varied from 0.46 to $2.6 \mathrm{ng} \cdot \mathrm{m}^{-3}$, with an average of $1.8 \mathrm{ng} \cdot \mathrm{m}^{-3}$ and from 8.2 to $20 \mathrm{ng} \cdot \mathrm{m}^{-3}$, with an average of $12 \mathrm{ng} \cdot \mathrm{m}^{-3}$, in the rainy and dry seasons, respectively (Fig. 6). These levels are lower than those measured during the dry season in the Ducke Forest Reserve (North area of the Amazon basin) (200-620 $\mathrm{ng} \cdot \mathrm{m}^{-3}$; average = $427 \mathrm{ng} \cdot \mathrm{m}^{-3}$ ) by Simoneit et al. (1990), but are of the same order of magnitude of those described by Graham et al. (2003b) (fine fraction = $13 \mathrm{ng} \cdot \mathrm{m}^{-3}$; coarse fraction $=23 \mathrm{ng} \cdot \mathrm{m}^{-3}$ ), during the dry season, in the Balbina region (North area of the Amazon basin).

The ratio $>C_{22} /<C_{20} n$-alkanoic acids under 1 (Table 3 ) and $C_{\max }$ at $\mathrm{C}_{10}$ in the rainy season and $\mathrm{C}_{16}$ in the dry season reflects microbial and phytoplankton contributions. The link between the clear dominance of $n$-alkanoic acids $<\mathrm{C}_{20}$ and the microbial or oceanic source of the organic aerosol has been described by Graham et al. (2003b), Kawamura et al. (2003) and Simoneit et al. (1990). The probability of being derived from phytoplankton from Amazon river and its tributaries or from Atlantic phytoplankton is not negligible taking into account the influence that the sampling site undergoes. The ACL values of $n$-alkanoic acids do not show variations along the two seasons (Table 3). During the rainy season, CPI (whole range) values showed a constant distribution with values always between 1.2 and 2.6. In the dry season values are much higher, ranging from 8.6 to 13 . These distributions are quite variable but it is according to that described by Simoneit et al. (1990). These values are strongly indicative of incorporation of biological constituents into the aerosol sample, especially in the dry season. In the dry season, it is observed that the presence of hexadecanoic $\left(C_{16: 0}\right)$ and octadecanoic $\left(C_{18: 0}\right)$ acid in large average concentrations, $5.1 \mathrm{ng} \cdot \mathrm{m}^{-3}$ and $3.1 \mathrm{ng} \cdot \mathrm{m}^{-3}$, respectively, indicating biological input.

In addition to the $n$-alkanoic acids, $n$-alkenoic acids, such as oleic $\left(\mathrm{C}_{18: 1}\right)$ and linoleic $\left(\mathrm{C}_{18: 2}\right)$ acids, were also detected in the Alenquer aerosol samples, mainly in the rainy season. Unsaturated $n$-fatty acids may also be issued to the atmosphere by biomass and coal burning, fossil fuel combustion, cooking, plants of terrestrial biosphere and also associated with sea salt aerosol, phytoplankton and marine bacteria (Oros and Simoneit, 2000, 2001; Rogge et al., 1993b; Schauer et al., 1999; Simoneit et al., 1988; Tervahattu et al., 2002). These acids are prone to oxidative processes and conversion to shorter chain species, which may explain the lower concentration observed in the dry season.

The $n$-alkanedioic acids are also present in these samples. The series ranged from $C_{3}$ to $C_{10}$, maximising at $C_{4}$, in both seasons. The total concentration varied from 2.0 to $11 \mathrm{ng} \cdot \mathrm{m}^{-3}$, with an average of $6.8 \mathrm{ng} \cdot \mathrm{m}^{-3}$, in the rainy season and from 24 to $55 \mathrm{ng} \cdot \mathrm{m}^{-3}$, with an average of $42 \mathrm{ng} \cdot \mathrm{m}^{-3}$, in the dry season. This type of acid is frequently present in atmospheric aerosols samples because it may have very different sources (Wu et al., 2015). Dicarboxylic acids $<C_{10}$ may have origin in combustion engines, meat cooking, pyrolysis of soil or plant constituents, or atmospheric oxidative processes. As example, the $C_{8}$ and $C_{9}$ compounds are formed by photo-oxidation of unsaturated $n$-alkenoic acids, such as oleic $\left(\mathrm{C}_{18: 1}\right)$ and linoleic $\left(\mathrm{C}_{18: 2}\right)$ acids (Gogou et al., 1996). Pereira et al. (1982) identified $n$-alkanedioic acids ranging from $\mathrm{C}_{4}$ to $\mathrm{C}_{9}$ in airborne ash resulting from pyrolysis of organic soil constituents, plants and trees.

A range of "other acids" were also identified and quantified. This group includes some resin acids, such isopimaric (rainy season -
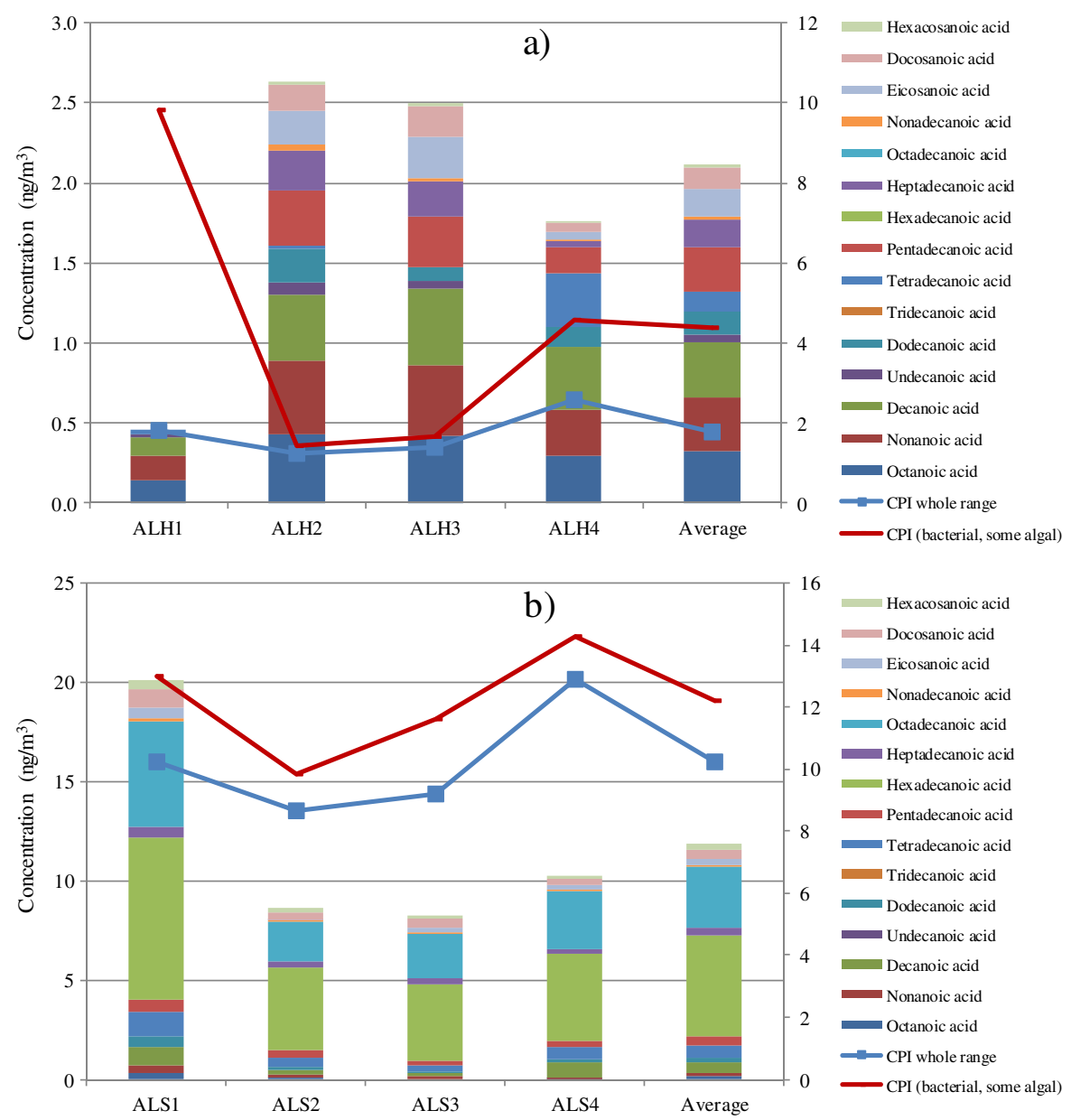

Fig. 6. Seasonal variation of concentration of n-alkanoic acids and CPI indexes in the rainy season (Fig. 6a) and dry season (Fig. 6b). 
a)

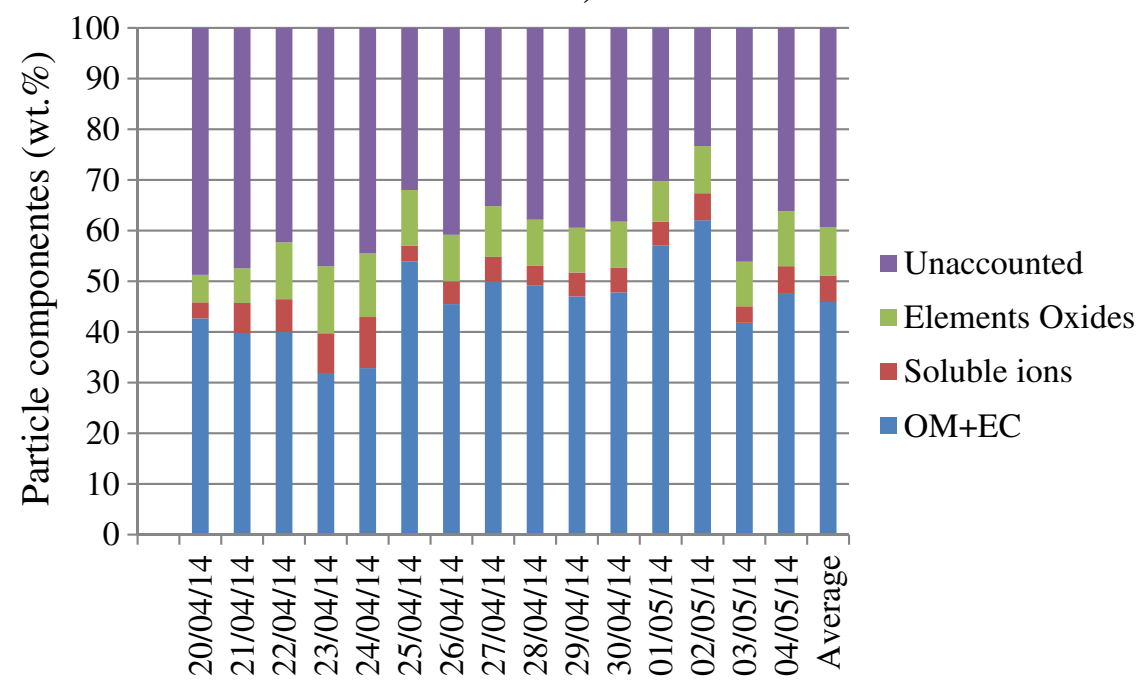

b)

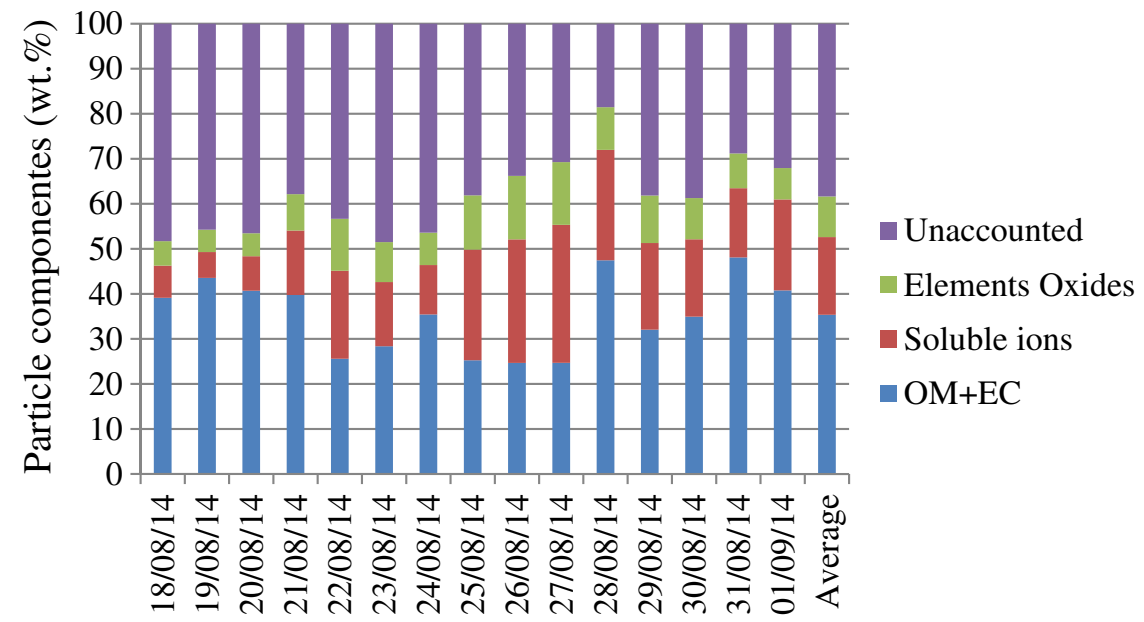

Fig. 7. Reconstructed TSP mass for the rainy season (Fig. 7a) and dry season (Fig. 7b).

$0.225 \mathrm{ng} \cdot \mathrm{m}^{-3}$; dry season $-0.049 \mathrm{ng} \cdot \mathrm{m}^{-3}$ ), dehydroabietic (rainy season $-0.184 \mathrm{ng} \cdot \mathrm{m}^{-3}$; dry season $-0.187 \mathrm{ng} \cdot \mathrm{m}^{-3}$ ) and abietic (rainy season $-0.009 \mathrm{ng} \cdot \mathrm{m}^{-3}$; dry season $-0.041 \mathrm{ng} \cdot \mathrm{m}^{-3}$ ). Other biomass burning tracers were also identified, such as syringic acid (rainy season $-0.036 \mathrm{ng} \cdot \mathrm{m}^{-3}$; dry season $-0.748 \mathrm{ng} \cdot \mathrm{m}^{-3}$ ) and vanillic acid (rainy season $-0.015 \mathrm{ng} \cdot \mathrm{m}^{-3}$; dry season $-0.187 \mathrm{ng} \cdot \mathrm{m}^{-3}$ ). These data contradict those described by Simoneit et al. (1988) who stated that these compounds were not detectable in aerosols from Amazonia, consistent with the absence of coniferous vegetation in this region. According to Souza (2010), the Brazilian phyto-geographical domain with the highest number of species of gymnosperms is Amazonia, with 16 species.

\subsection{Mass balance}

Taking into account the gravimetric data and all identified aerosol species, it is possible to perform a mass balance (chemically analysed mass vs. gravimetrically determined mass). For this, it is necessary to determine the organic matter (OM) from OC measurements. OM is estimated by using a factor $(f)$ that accounts for the oxygen, hydrogen, nitrogen, and sulfur present in the organic material (McMeeking et al., 2009). The organic mass to organic carbon ratio (OM/OC) takes values between 1.3 and 2.2 (Chazette and Liousse, 2001; Hegg et al., 1997;
Pöschl, 2005; Reid et al., 2005; Turpin and Lim, 2001), depending on the aerosol origin, its composition and the aerosol aging level (Puxbaum and Tenze-Kunit, 2003; Stelson and Seinfeld, 1981). The $f$ value used in this study was 1.8 (Temesi et al., 2001). Thus, the equation used to reconstruct the TSP mass was as follows (Chow et al., 2015):

$\mathrm{TSP}=\sum_{\text {Soluble ions }}+\sum_{\text {Element oxides }}+\mathrm{EC}+\mathrm{OC} \times f$

Elements were assumed to exist in their common oxide forms (e.g. $\mathrm{Al}_{2} \mathrm{O}_{3}, \mathrm{CaO}, \mathrm{K}_{2} \mathrm{O}, \mathrm{Fe}_{2} \mathrm{O}_{3}$, etc.). The calculated sum of analysed aerosol constituents corresponds, on average, to $61 \%$ and $62 \%$ of the TSP weighted, in rainy and dry seasons, respectively (Fig. 7). The unknown mass may be due to some components not determined and absorption of water by the aerosol (Temesi et al., 2001), since sampling was carried out under at very high relative humidity conditions.

\section{Conclusions}

In this study, a detailed chemical characterisation of the total suspended particulate matter (TSP) from an Amazonia remote region was performed, to look for seasonal patterns and to identify potential emission sources and formation processes. Analyses included watersoluble ions, principal elements, carbonaceous content (OC, EC and 
TC), and the identification and quantification of approximately 115 organic compounds.

Throughout the study it was observed that during the rainy season, the Alenquer region was mostly affected by air masses with Atlantic origin that develop along the Amazon river. By contrast, during the dry season most of the air masses went through different northern states bringing a continental influence, before arriving to the study site. With respect to TSP, a higher mean concentration $\left(31 \pm 7.8 \mu \mathrm{g} \cdot \mathrm{m}^{-3}\right)$ was obtained for the dry season in comparison with the rainy season (14 \pm $1.3 \mu \mathrm{g} \cdot \mathrm{m}^{-3}$ ). The water-soluble ions accounted, on average, for $7 \%$ and $18 \%$ during the rainy and dry seasons, respectively, of the concentration of TSP. In the rainy season the dominant ions were $\mathrm{SO}_{4}^{2-}, \mathrm{Na}^{+}$, $\mathrm{NO}_{3}^{-}$and $\mathrm{Cl}^{-}$. In the dry season, in general, an increase of concentrations of all ions was registered, especially for $\mathrm{Mg}^{2+}, \mathrm{Na}^{+}, \mathrm{Cl}^{-}$and $\mathrm{SO}_{4}^{2-}$. In the rainy season, the $\mathrm{Na}^{+}, \mathrm{Cl}^{-}$and $\mathrm{Mg}^{2+}$ were strongly associated with a marine source, whereas in the dry season an enrichment of $\mathrm{Na}^{+}$, probably from soil, was observed. In the dry season, the $\mathrm{SO}_{4}^{2-}, \mathrm{NO}_{3}^{-}$and $\mathrm{K}^{+}$ mean concentrations were higher due to much less wet scavenging, as well as to the biomass burning plumes from forest fires in Pará state and in other states, which are transported with the air masses and reach the sampling site. In the rainy season, the principal elements were $\mathrm{Na}, \mathrm{Ca}$ and $\mathrm{K}$. In the dry season, increased concentrations were observed, especially for Mn, Fe and Mg. As observed for the corresponding water soluble ions, the enrichment observed for $\mathrm{Na}$ and $\mathrm{Mg}$, especially in the rainy season, is explained by the influence of the marine aerosol. The individual elemental concentrations obtained in this study are quite comparable to the values reported for rainy and dry season background aerosol in the north area of the Amazon basin.

The carbonaceous content of the Alenquer particulate matter is higher than values observed in central Amazonia, regardless of the season, and also than values observed in southern Amazonia during the rainy season. The primary inputs of organic constituents to the aerosols of Alenquer based on the homologous compound series and biomarkers were: (i) natural emissions from terrestrial higher plant waxes, particularly in dry season, which is expressed, for example, by the $n$-alkane series with an odd carbon number predominance; (ii) anthropogenic emissions from diesel fuel combustion and biomass combustion, predominating during the dry season given, for example, by the presence of $n$-alkene with an even carbon number predominance; and by the $n$-alkanoic acids distribution characterised by an even carbon number preference and together with the CPI values of 10 , strongly indicative of incorporation of biological constituents into the aerosol sample. In Alenquer, PAH were found in all samples, but at low concentrations. Contrary to what would be expected some resin acids (isopimaric acid, dehydroabietic acid and abietic acid) and other biomass burning tracers such syringic acid and vanillic acid were identified. The inorganic and organic compounds found in particulate matter could be conducive to source apportionment studies and will contribute to the improvement of emission inventories in the Amazonia remote region.

\section{Acknowledgements}

This work was funded by the "Coordenação de Aperfeiçoamento de Pessoal de Nível Superior" (CAPES) through the project "Unravelling chemical fingerprints of atmospheric aerosols from contrasting Brazilian regions", CAPES 041/2012 and AUXPE 1446/2013.

The assistance provided by Margareth Sugano from Isotope Geology Laboratory of the Institute of Geosciences of Unicamp - Campinas, Brazil, by Luciana Souza Alves and Michele Lima de Souza from Department of Analytical Chemistry of the Institute of Chemistry of UNESP Araraquara, Brazil and by Sónia Rocha and Danilo Custódio from CESAM laboratory of the University of Aveiro, Portugal was much appreciated. Thanks also the collaboration in the work field by the scientific initiation student Jozinei Ferreira Lopes from UFOPA, Santarém, Brazil; and to Nikolas Marinos which allowed the installation of the sampling station on his property and gave all the necessary support for the success of the two field campaigns conducted during this study.

\section{Appendix A. Supplementary data}

Supplementary data to this article can be found online at http://dx. doi.org/10.1016/j.atmosres.2016.07.027.

\section{References}

Abas, M.R.B., Simoneit, B.R.T., 1996. Composition of extractable organic matter of air particles from Malaysia: initial study. Atmos. Environ. 30, 2779-2793.

Abas, M.R.B., Simoneit, B.R.T., 1997. Gas chromatographic and gas chromatographic-mass spectrometric characterization of biogenic and petrogenic organic matter in the atmosphere. Malays. J. Anal. Sci. 3, 9-23.

Alves, C.A., 2008. Characterisation of solvent extractable organic constituents in atmospheric particulate matter: an overview. An. Acad. Bras. Ciências 80, 21-82.

Alves, C., Oliveira, T., Pio, C., Silvestre, A.J.D., Fialho, P., Barata, F., Legrand, M., 2007. Characterisation of carbonaceous aerosols from the Azorean Island of Terceira. Atmos. Environ. 41, 1359-1373.

Alves, C.A., Vicente, A., Monteiro, C., Gonçalves, C., Evtyugina, M., Pio, C., 2011. Emission of trace gases and organic components in smoke particles from a wildfire in a mixedevergreen forest in Portugal. Sci. Total Environ. 409, 1466-1475.

Alves, C.A., Gomes, J., Nunes, T., Duarte, M., Calvo, A., Custodio, D., Pio, C., Karanasiou, A Querol, X., 2015. Size-segregated particulate matter and gaseous emissions from motor vehicles in a road tunnel. Atmos. Res. 153, 134-144.

Andreae, M.O., Crutzen, P.J., 1997. Atmospheric aerosols: biogeochemical sources and role in atmospheric chemistry. Science 276, 1052-1058.

Andreae, M.O., Merlet, P., 2001. Emission of trace gases and aerosols from biomass burning. Glob. Biogeochem. Cycles 15, 955-966.

Andreae, M.O., Artaxo, P., Brandão, C., Carswell, F.E., Ciccioli, P., da Costa, A.L., Culf, A.D., Esteves, J.L., Gash, J.H.C., Grace, J., Kabat, P., Lelieveld, J., Malhi, Y., Manzi, A.O., Meixner, F.X., Nobre, A.D., Nobre, C., Ruivo, M.D.L.P., Silva-Dias, M.A., Stefani, P., Valentini, R., Jouanne, J.V., Waterloo, M.J., 2002. Biogeochemical cycling of carbon, water, energy, trace gases, and aerosols in Amazonia: the LBA-EUSTACH experiments. J. Geophys. Res. 107, 8066.

Arana, A., Artaxo, P., 2014. Composiç̃o elementar do aerossol atmosférico na região central da Bacia Amazônica. Quim Nova 37, 268-276.

Artaxo, P., Hansson, H.C., 1995. Size distribution of biogenic aerosol particles from the Amazon Basin. Atmos. Environ. 29, 393-402.

Artaxo, P., Storms, H., Bruynseels, F., Grieken, R.V., Maenhaut, W., 1988. Composition and sources of aerosols from the Amazon Basin. J. Geophys. Res. 93, 1605-1615.

Artaxo, P., Maenhaut, W., Storms, H., Grieken, R.V., 1990. Aerosol characteristics and sources for the Amazon Basin during the wet season. J. Geophys. Res. 95, 16971-16985.

Artaxo, P., Martins, J.V., Yamasoe, M.A., Procopio, A.S., Pauliquevis, T.M., Andreae, M.O. Guyon, P., Gatti, L.V., Leal, A.M.C., 2002. Physical and chemical properties of aerosols in the wet and dry seasons in Rondônia, Amazonia. J. Geophys. Res. Atmos. 107, 8081

Bush, R.T., McInerney, F.A., 2013. Leaf wax n-alkane distributions in and across modern plants: implications for paleoecology and chemotaxonomy. Geochim. Cosmochim. Acta $117,161-179$.

Calvo, A.I., Alves, C., Castro, A., Pont, V., Vicente, A.M., Fraile, R., 2013. Research on aerosol sources and chemical composition: past, current and emerging issues. Atmos. Res. $120,1-28$.

Cao, J.J., Lee, S.C., Ho, K.F., Zou, S.C., Fung, K., Li, Y., Watson, J.G., Chow, J.C., 2004. Spatial and seasonal variations of atmospheric organic carbon and elemental carbon in Pearl River Delta region, China. Atmos. Environ. 38, 4447-4456.

Chazette, P., Liousse, C., 2001. A case of study of optical and chemical ground apportionment for urban aerossols in Thessaloniki. Atmos. Environ. 35, 2497-2506.

Chen, Q., Farmer, D.K., Schneider, J., Zorn, S.R., Heald, C.L., Karl, T.G., Guenther, A., Allan, J.D., Robinson, N., Coe, H., Kimmel, J.R., Pauliquevis, T., Borrmann, S., Pöschl, U., Andreae, M.O., Artaxo, P., Jimenez, J.L., Martin, S.T., 2009. Mass spectral characterization of submicron biogenic organic particles in the Amazon Basin. Geophys. Res. Lett. 36, L20806.

Chesselet, R., Morelli, J., Buat-Menard, P., 1972. Variations in ionic ratios between reference sea water and marine aerosols. J. Geophys. Res. 77, 5116-5131.

Chow, J.C., Lowenthal, D.H., Chen, L.-W.A., Wang, X., Watson, J.G., 2015. Mass reconstruction methods for $\mathrm{PM}_{2.5}$ : a review. Air Qual. Atmos. Health 8, 243-263.

Claeys, M., Graham, B., Vas, G., Wang, W., Vermeylen, R., Pashynska, V., Cafmeyer, J., Guyon, P., Andreae, M.O., Artaxo, P., Maenhaut, W., 2004. Formation of secondary organic aerosols through Photooxidation of isoprene. Science 303, 1173-1176.

Crozat, G., 1979. Sur l'émission d'un aérosol riche en potassium par la forêt tropicale. Tellus 31, 52-57.

Draxler, R.R., 1999. HYSPLIT4 User's Guide. NOAA Tech. Memo. ERL ARL-230. NOAA Air Resources Laboratory, Silver Spring, MD.

Draxler, R.R., Hess, G.D., 1997. Description of the HYSPLIT_4 Modeling System. NOAA Tech. Memo. ERL ARL-224. NOAA Air Resources Laboratory, Silver Spring, MD, p. 24

Draxler, R.R., Hess, G.D., 1998. An overview of the HYSPLIT_4 modeling system of trajectories, dispersion, and deposition. Aust. Meteorol. Mag. 47, 295-308.

Echalar, F., Artaxo, P., Martins, J.V., Yamasoe, M., Gerab, F., Maenhaut, W., Holben, B., 1998 Long-term monitoring of atmospheric aerosols in the Amazon Basin: source identification and apportionment. J. Geophys. Res. 103, 31849-31864.

Falesi, I.C., 1971. Solos Do Distrito Agropecuário Da Suframa. Série: Solos. 1ª ed. Instituto de Pesquisas e Experimentação Agropecuárias da Amazônia Ocidental, Manaus. 
Feitosa, F.A.C., Manoel Filho, J. (Eds.), 1997. Hidrogeologia: Conceitos e Aplicações. CPRM Serviço Geológico do Brasil, Fortaleza, Brasil (412 pp.).

Formenti, P., Andreae, M.O., Lange, L., Roberts, G., Cafmeyer, J., Rajta, I., Maenhaut, W. Holben, B.N., Artaxo, P., Lelieveld, J., 2001. Saharan dust in Brazil and Suriname during the large-scale biosphere-atmosphere experiment in Amazonia (LBA) - cooperative LBA regional experiment (CLAIRE) in march 1998. J. Geophys. Res. 106, 14919-14934

Gogou, A., Stratigakis, N., Kanakidou, M., Stephanou, E.G., 1996. Organic aerosols in eastern Mediterranean: components source reconciliation by using molecular markers and atmospheric back trajectories. Org. Geochem. 25, 79-96.

Gonçalves, C., Figueiredo, B.R., 2015. Atmospheric particulate matter from Amazon region - sources and properties. Contrib. Geol. Amazon. Soc. Bras. Geol. 9, 235-249.

Graham, B., Guyon, P., Maenhaut, W., Taylor, P.E., Ebert, M., Matthias-Maser, S., MayolBracero, O.L., Godoi, R.H.M., Artaxo, P., Meixner, F.X., Lima Moura, M.A., D'Almeida Rocha, C.H.E., Grieken, R.V., Glovsky, M.M., Flagan, R.C., Andreae, M.O., 2003a. Composition and diurnal variability of the natural Amazonian aerosol. J. Geophys. Res. 108, 4765.

Graham, B., Guyon, P., Taylor, P.E., Artaxo, P., Maenhaut, W., Glovsky, M.M., Flagan, R.C. Andreae, M.O., 2003b. Organic compounds present in the natural Amazonian aerosol: characterization by gas chromatography-mass spectrometry. J. Geophys. Res. 108 4766.

Guyon, P., Graham, B., Roberts, G.C., Mayol-Bracero, O.L., Maenhaut, W., Artaxo, P., Andreae, M.O., 2003. In-canopy gradients, composition, sources, and optical properties of aerosol over the Amazon forest. J. Geophys. Res. 108, 4591.

Halsall, C.J., Barrie, L.A., Fellin, P., Muir, G.C., Billeck, B.N., Lockhart, L., Rovindsky, F.Y., Kononov, E.Y., Pastuklov, B., 1997. Spatial and temporal variation of polycyclic aromatic hydrocarbons in the Arctic atmosphere. Environ. Sci. Technol. 31, 3593-3599.

Hegg, D.A., Livingston, J., Hobbs, P.V., Novakov, T., Russell, P., 1997. Chemical apportionment of aerosol columm depth off mid-Atlantic coast of the United States. J. Geophys. Res. 102, 25293-25303.

IBGE - Instituto Brasileiro de Geografia e Estatística, 2015. http://cidades.ibge.gov.br/ xtras/perfil.php?lang $=\&$ codmun $=150040$ (Accessed in: 07/2015) .

INPE - Instituto Nacional de Pesquisas Espaciais, 2015. Sistemas de Informações Geográficas e banco de dados de todos Focos. http://www.dpi.inpe.br/proarco/ bdqueimadas/ (Accessed in: 26/09/2015).

Kawamura, K., Ishimura, Y., Yamazaki, K., 2003. Four years' observations of terrestrial lipid class compounds in marine aerosols from the western North Pacific. Glob. Biogeochem. Cycles 17, 1003.

Kesselmeier, J., Kuhn, U., Wolf, A., Andreae, M., Ciccioli, P., Brancaleoni, E., Frattoni, M. Guenther, A., Greenberg, J., Vasconcellos, P., 2000. Atmospheric volatile organic compounds (VOC) at a remote tropical forest site in central Amazonia. Atmos. Environ. 34, 4063-4072.

Konhauser, K.O., Fyfe, W.S., Kronberg, B.I., 1994. Multi-element chemistry of some Amazonian waters and soils. Chem. Geol. 111, 155-175.

Krauss, M., Wilcke, W., Martius, C., Bandeira, A.G., Garcia, M.V.B., Amelung, W., 2005. Atmospheric versus biological sources of polycyclic aromatic hydrocarbons (PAHs) in a tropical rain forest environment. Environ. Pollut. 135, 143-154.

Kumar, P., Yadav, S., 2016. Seasonal variations in water soluble inorganic ions, OC and EC in $\mathrm{PM}_{10}$ and $\mathrm{PM}>10$ aerosols over Delhi: influence of sources and meteorological factors. Aerosol Air Qual. Res. 16, 1165-1178.

Lai, S.C., Zou, S.C., Cao, J.J., Lee, S.C., Ho, K.F., 2007. Characterizing ionic species in $\mathrm{PM}_{2.5}$ and $\mathrm{PM}_{10}$ in four Pearl River Delta cities, South China. J. Environ. Sci. 19, 939-947.

Martin, S.T., Andreae, M.O., Artaxo, P., Baumgardner, D., Chen, Q., Goldstein, A.H. Guenther, A., Heald, C.L., Mayol-Bracero, O.L., McMurry, P.H., Pauliquevis, T., Pöschl, U., Prather, K.A., Roberts, G.C., Saleska, S.R., Silva Dias, M.A., Spracklen, D.V., Swietlicki, E., Trebs, I., 2010. Sources and properties of Amazonian aerosol particles. Rev. Geophys. 48, RG2002. http://dx.doi.org/10.1029/2008RG000280.

McMeeking, G.R., Kreidenweis, S.M., Baker, S., Carrico, C.M., Chow, J.C., Collett Jr., J.L., Hao, W.M., Holden, A.S., Kirchstetter, T.W., Malm, W.C., Moosmuller, H., Sullivan, A.P. Wold, C.E., 2009. Emissions of trace gases and aerosols during the open combustion of biomass in the laboratory. J. Geophys. Res. 114, D19210. http://dx.doi.org/10. 1029/2009JD011836.

Oros, D.R., Simoneit, B.R.T., 2000. Identification and emission rates of molecular tracers in coal smoke particulate matter. Fuel 79, 515-536.

Oros, D.R., Simoneit, B.R.T., 2001. Identification and emission factors of molecular tracers in organic aerosols from biomass burning part 1. Temperate climate conifers. Appl. Geochem. 16, 1513-1544.
Pereira, W.E., Rostad, C.E., Taylor, H.E., Klein, J.M., 1982. Characterization of organic contaminants in environmental samples associated with Mount St. Helens 1980 volcanic eruption. Environ. Sci. Technol. 16, 387-396.

Pio, C., Cerqueira, M., Harrison, R.M., Nunes, T., Mirante, F., Alves, C., Oliveira, C., Campa, A.S.D.L., Artíñano, B., Matos, M., 2011. OC/EC ratio observations in Europe: rethinking the approach for apportionment between primary and secondary organic carbon. Atmos. Environ. 45, 6121-6132.

Pöschl, U., 2005. Atmospheric aerosols: composition, transformation, climate and health effects. Angew. Chem. Int. Ed. Engl. 44, 7520-7540.

Puxbaum, H., Tenze-Kunit, M., 2003. Size distribution and seasonal variation of atmospheric cellulose. Atmos. Environ. 37, 3693-3699.

Puxbaum, H., Gomiscek, B., Kalina, M., Bauer, H., Salam, A., Stopper, S., Preining, O., Hauck, H., 2004. A dual site study of PM2.5 and PM10 aerosol chemistry in the larger region of Vienna, Austria. Atmos. Environ. 38, 3949-3958.

Reid, J.S., Koppmann, R., Eck, T.F., Eleuterio, D.P., 2005. A review of biomass burning emissions part II: intensive physical properties of biomass burning particles. Atmos. Chem. Phys. 5, 799-825.

Rogge, W.F., Hildemann, L.M., Mazurek, M.A., Cass, G.R., Simoneit, B.R.T., 1993a. Sources of fine organic aerosol: 2 . Noncatalyst and catalyst-equipped automobiles and heavyduty diesel trucks. Environ. Sci. Technol. 27, 636-651.

Rogge, W.F., Mazurek, M.A., Hildemann, L.M., Cass, G.R., Simoneit, B.R.T., 1993b. Quantification of urban organic aerosols on a molecular level: identification, abundance and seasonal variation. Atmos. Environ. 27A, 1309-1330.

Schauer, J.J., Rogge, W.F., Hildemann, L.M., Mazurek, M.A., Cass, G.R., Simoneit, B.R.T., 1996. Source apportionment of airborne particulate matter using organic compounds as tracers. Atmos. Environ. 30, 3837-3855.

Schauer, J.J., Kleeman, M.J., Cass, G.R., Simoneit, B.R.T., 1999. Measurement of emissions from air pollution sources. 1. C-1 through C-29 organic compounds from meat charbroiling. Environ. Sci. Technol. 33, 1566-1577.

Silva Junior, O.M., Szlafsztein, C.F., 2013. A Importância dos Conceitos de Ameaça, Vulnerabilidade e Risco em Planos Diretores Municipais: Estudo de Caso no Município de Alenquer (Pará). Rev. Geoamazônia 1, 64-80.

Simoneit, B.R.T., Cox, R.E., Standley, L.J., 1988. Organic matter of the troposphere-IV. Lipids in harmattan aerosols of Nigeria. Atmos. Environ. 22, 983-1004.

Simoneit, B.R.T., Cardoso, J.N., Robinson, N., 1990. An assessment of the origin and composition of higher molecular weight organic matter in aerosols over Amazonia. Chemosphere 21, 1285-1301.

Souza, V.C., 2010. Introdução: as gimnospermas do Brasil. In: Forzza, RC., org., et al. Instituto de Pesquisas Jardim Botânico do Rio de Janeiro. Catálogo de plantas e fungos do Brasil [online]. Rio de Janeiro: Andrea Jakobsson Estúdio: Instituto de Pesquisa Jardim Botânico do Rio de Janeiro, 75-77. Vol. 1. ISBN 978-85-8874-242-0.

Stelson, A.W., Seinfeld, J.H., 1981. Chemical mass accounting of urban aerosol. Environ. Sci. Technol. 15, 671-679.

Swap, R., Garstang, M., Greco, S., Talbot, R., Kållberg, P., 1992. Saharan dust in the Amazon Basin. Tellus 44, 133-149.

Temesi, D., Molnár, A., Mészáros, E., Feczkó, T., Gelencsér, A., Kiss, G., Krivácsy, Z., 2001. Size resolved chemical mass balance of aerosol particles over rural Hungary. Atmos. Environ. 35, 4347-4355.

Tervahattu, H., Hartonen, K., Kerminen, V.M., Kupiainen, K., Aarnio, P., Koskentalo, T., Tuck, A.F., Vaida, V., 2002. New evidence of an organic layer on marine aerosols. J. Geophys. Res. Atmos. 107, 4053.

Turpin, B.J., Lim, H.J., 2001. Species contributions to PM2.5 mass concentrations: revisiting common assumptions for estimating organic mass. Aerosol Sci. Technol. 35, 602-610.

Vasconcellos, P.C., Artaxo, P.E., Ciccioli, P., Cecinato, A., Brancaleoni, E., Frattoni, M., 1998. Determinação dos hidrocarbonetos saturados e policíclicos aromáticos presentes no material particulado da atmosfera amazônica. Quím. Nova 21, 385-393.

Vasconcellos, P.C., Balasubramanian, R, Bruns, R.E, Sanchez-Ccoyllo, O., Andrade, M.F. Flues, M., 2007. Water-soluble ions and trace metals in airborne particles over urban areas of the state of São Paulo, Brazil: influences of local sources and long range transport. Water Air Soil Pollut. 186, 63-73.

Vicente, A., Alves, C., Calvo, A.I., Fernandes, A.P., Nunes, T., Monteiro, C., Almeida, S.M., Pio, C., 2013. Emission factors and detailed chemical composition of smoke particles from the 2010 wildfire season. Atmos. Environ. 71, 295-303.

Wu, S.P., Schwab, J., Liu, B.L., Li, T.C., Yuan, S.S., 2015. Seasonal variations and source identification of selected organic acids associated with PM10 in the coastal area of Southeastern China. Atmos. Res. 155, 37-51. 